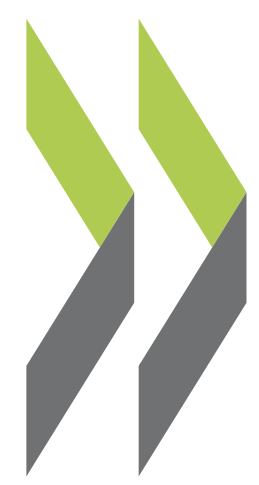

OECD Economics Department Working Papers No. 1008

Reducing Poverty in Estonia Through Activation and Better Targeting

Sarah Flèche, Artur Radziwill 
Organisation de Coopération et de Développement Économiques

Organisation for Economic Co-operation and Development

10-Dec-2012

ECONOMICS DEPARTMENT

English - Or. English

REDUCING POVERTY IN ESTONIA THROUGH ACTIVATION AND BETTER TARGETING

ECONOMICS DEPARTMENT WORKING PAPERS No. 1008

By Sarah Flèche and Artur Radziwill

All Economics Department Working Papers are available through the OECD's Internet website at http://www.oecd.org/eco/Workingpapers

JT03332485

Complete document available on OLIS in its original format

This document and any map included herein are without prejudice to the status of or sovereignty over any territory, to the delimitation of international frontiers and boundaries and to the name of any territory, city or area. 


\section{ABSTRACT/RÉSUMÉ \\ Reducing poverty in Estonia through activation and better targeting}

The crisis revealed the need for a strategic review of the existing social protection system in Estonia. Extreme income fluctuations on one side and low social benefits on the other side exposed fragile groups in the population to a significant poverty risk. The government has recently commissioned several studies to prepare a systematic reform of the system. The spectrum of options is wide and includes increased generosity, further efficiency gains, strengthening incentives, better access to services and more ambitious activation. In particular, all support programmes should be designed to maximise the prospects of re-integrating beneficiaries into employment. Social benefit recipients should therefore become regular clients of the unemployment insurance offices, and they should benefit from job search assistance and active labour market policies. Scarce resources should be more targeted to those in greatest need. Addressing the large inflows into the disability system is a priority.

This Working Paper relates to the 2012 OECD Economic Survey of Estonia, www.oecd.org/eco/surveys/estonia2012.htm.

JEL classification: E32; I18; I38; J13; J21; J65

Keywords: Estonia; volatility; flexibility; well-being; unemployment; active labour market policies; social policy; inequality; poverty; disability; parental benefits; healthcare; taxation

\section{Réduire la pauvreté en Estonie par des politiques d'activation plus ambitieuses et un meilleur ciblage des aides}

La crise a mis à jour la nécessité d'un examen stratégique du système de protection sociale en Estonie. Les fortes fluctuations de revenus combinées au faible niveau des prestations sociales exposent les groupes les plus fragiles de la population à un risque significatif de pauvreté. Le gouvernement a récemment commandité plusieurs études visant à préparer une réforme généralisée du système. Les possibilités de réformes sont larges et incluent un renforcement de la générosité des prestations, un accroissement des gains d'efficacité, un renforcement des incitations, un meilleur accès aux services et une politique d'activation plus ambitieuse. Tous les programmes de soutien devraient être conçus de façon à maximiser les perspectives de retour à l'emploi des bénéficiaires. Il faudrait par conséquent que les allocataires de prestations sociales fréquentent plus régulièrement les services de l'assurance-chômage, et qu'ils bénéficient d'une aide à la recherche d'emploi et de politiques actives du marché du travail. Les ressources rares devraient être ciblées davantage sur ceux qui en ont le plus grand besoin. Il faut en priorité endiguer les entrées en masse dans le régime d'invalidité.

Ce document de travail se rapporte à l'Etude économique de l'OCDE sur l'Estonie 2012 www.oecd.org/eco/etudes/estonie2012.htm.

\section{Classification JEL: E32; I18; I38; J13; J21; J65}

Mots clés: Estonie; volatilité; flexibilité; bien-être; chômage; politiques actives du marché du travail; politiques sociales; inégalités; pauvreté ; régime d’invalidité; prestations sociales; soins de santé; fiscalité

\section{(c) OECD (2012)}

You can copy, download or print OECD content for your own use, and you can include excerpts from OECD publications, databases and multimedia products in your own documents, presentations, blogs, websites and teaching materials, provided that suitable acknowledgment of OECD as source and copyright owner is given. All requests for commercial use and translation rights should be submitted to rights@oecd.org. 


\section{TABLE OF CONTENTS}

\section{REDUCING POVERTY IN ESTONIA THROUGH ACTIVATION AND BETTER TARGETING. 5}

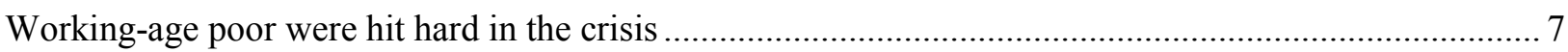

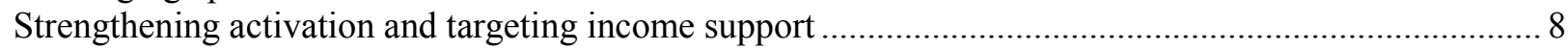

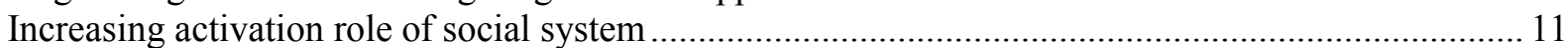

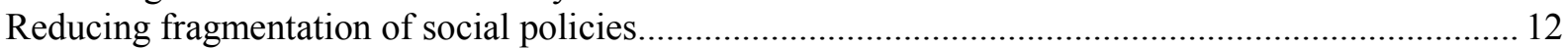

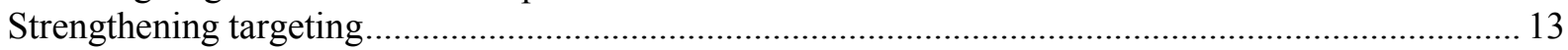

Reforming the disability system to promote the earnings capacity ..................................................... 15

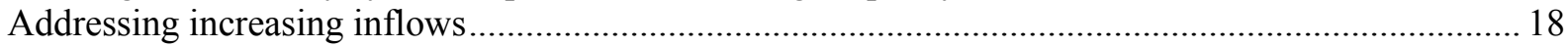

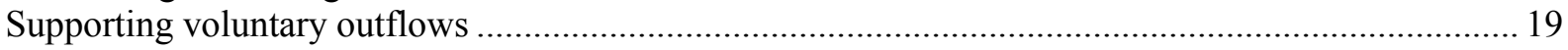

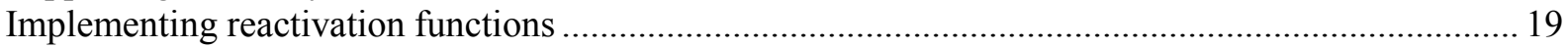

Reducing institutional complexity and case-managing clients .......................................................... 20

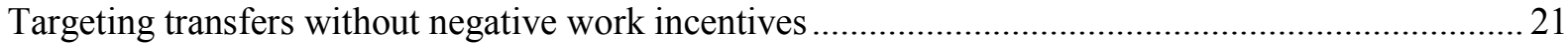

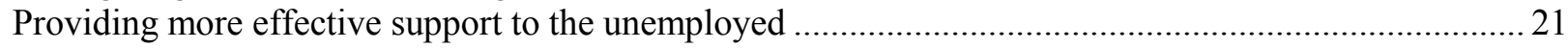

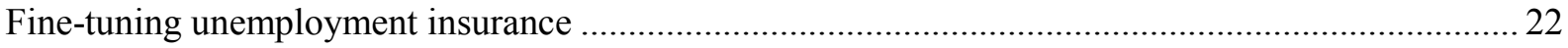

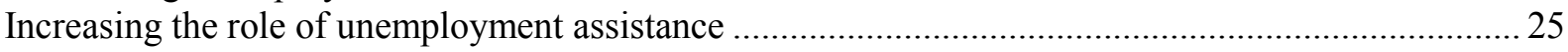

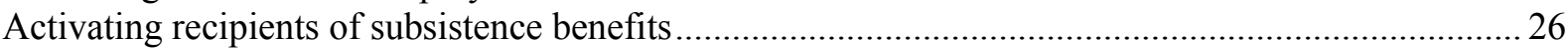

Re-adjusting different social benefit schemes addressed to the working-age population .................... 28

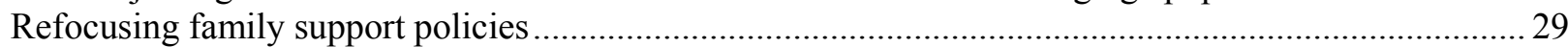

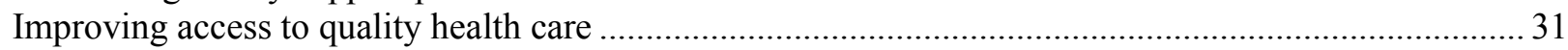

Reducing the labour tax wedge for the most vulnerable ..................................................................... 35

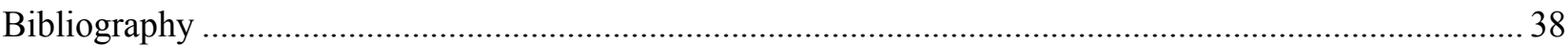

A nnex A 1. Risk-of-poverty rates by main categories..................................................................... 42

A nnex A2. Macroeconomic volatility and life satisfaction in Estonia: regression results .................... 43

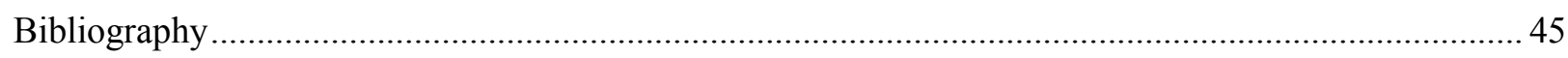

\section{Tables}

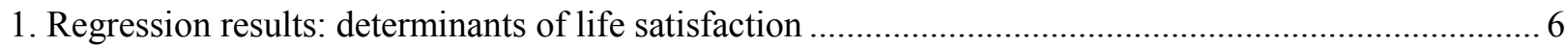

2. Means-testing of unemployment assistance in OECD countries...................................................... 26

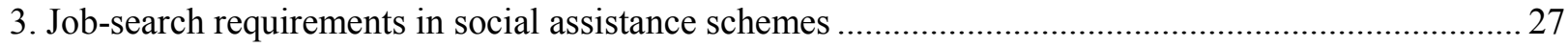

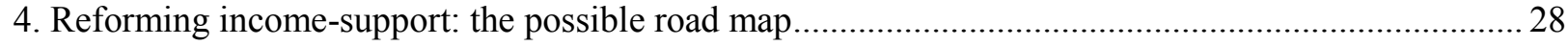

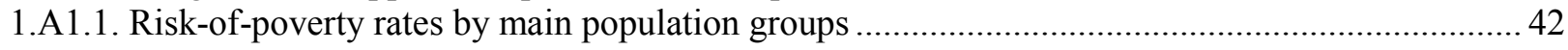

1.A1.2 Detailed regression results: determinant of life satisfaction..................................................... 44 


\section{Figures}

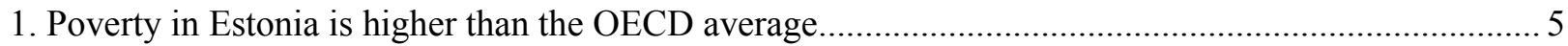

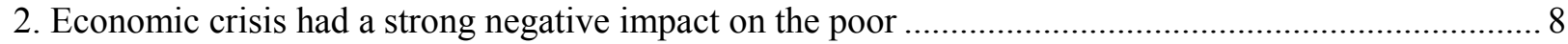

3. Transfers (other than old-age pensions) are small and untargeted with limited impact on inequality .... 9

4. The poverty among unemployed is among the highest in the EU ..................................................... 10

5. There is scope to simultaneously lower poverty and increase employment....................................... 11

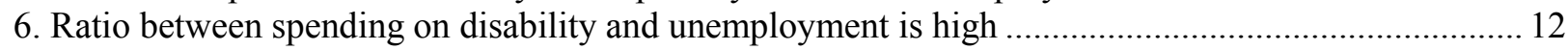

7. The size of spending on income-tested programmes is the lowest in the OECD............................... 14

8. Disability is the only large transfer program that redistributes to the poor ........................................ 15

9. The number of permanent incapacity to work benefit recipients increased rapidly in the crisis .......... 17

10. Disability system is not generous, but does not promote outflows ............................................. 18

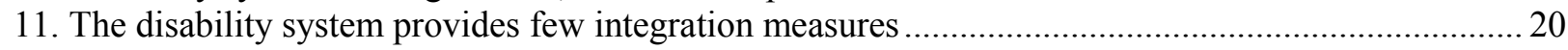

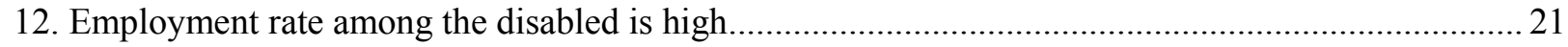

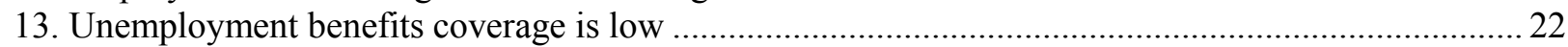

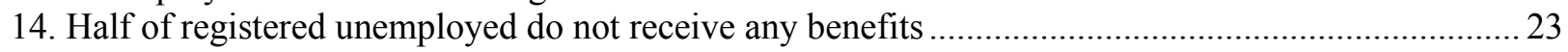

15. Employment record requirements are relatively strict compared to job search obligations.................24

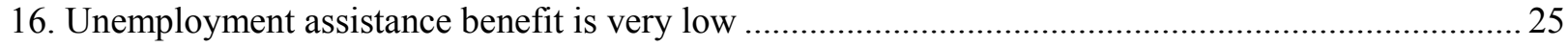

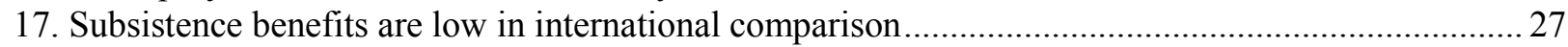

18. Maternity and paternity leaves are exceptionally generous in Estonia ..............................................29

19. There is still much scope to increase both fertility and female employment rates............................... 30

20. Low spending on childcare might contribute to low enrolment rates ............................................. 31

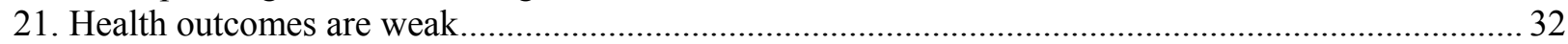

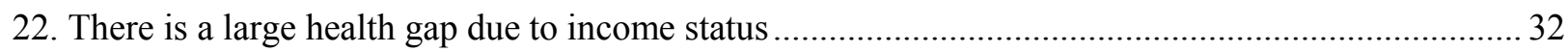

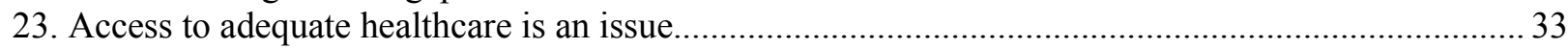

24. High share of out-of-pockets spending on pharmaceuticals contributes to unequal access ................ 34

25. Low-earners face high labour tax wedge that discourages employment ............................................ 36

26. Property taxation is the source of potentially large non-distortionary revenues ................................. 37

\section{Boxes}

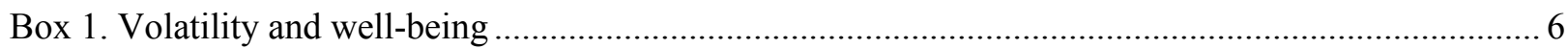

Box 2. Two tier unemployment protection and social assistance..................................................... 9

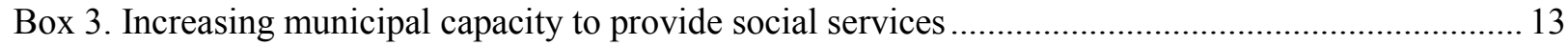

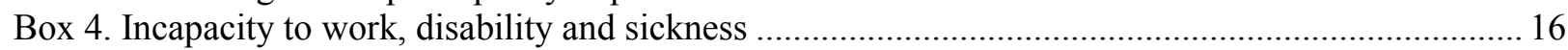

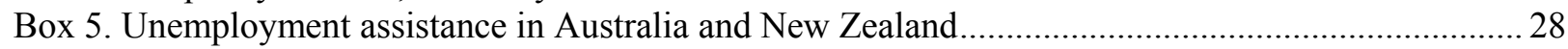

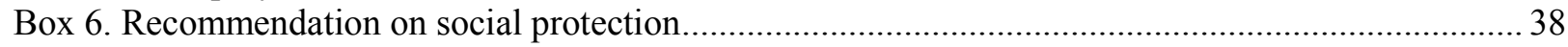

The statistical data for Israel are supplied by and under the responsibility of the relevant Israeli authorities. The use of such data by the OECD is without prejudice to the status of the Golan Heights, East Jerusalem and Israeli settlements in the West Bank under the terms of international law. 
ECO/WKP(2012)85

\title{
REDUCING POVERTY IN ESTONIA THROUGH ACTIVATION AND BETTER TARGETING
}

\author{
By Sarah Flèche and Artur Radziwill ${ }^{1}$
}

The strategic goal of Estonia is to lower poverty to $15 \%$ by 2020 . Relative poverty equalled $21 \%$, as measured at $60 \%$ of median income adjusted for household size, which was above the OECD average in 2008 (Figure 1). More positively, the poverty gap, which measures mean income necessary to reach the poverty threshold, is in fact narrower than OECD average, and material deprivation is also moderate. The risk of poverty is strongly determined by educational attainment and employment status, which also largely explain high regional disparities (Annex 1). Households without work are by far the most exposed to poverty. However, people above 65 , whose relative poverty rates were highest and deteriorating prior to the crisis, are currently at lower poverty risk, reflecting the robustness of old age income replacement schemes despite the deep crisis.

Figure 1. Poverty in Estonia is higher than the OECD average

Relative poverty rates ${ }^{1}$ at 40,50 and $60 \%$ of median income thresholds, latest year ${ }^{2}$

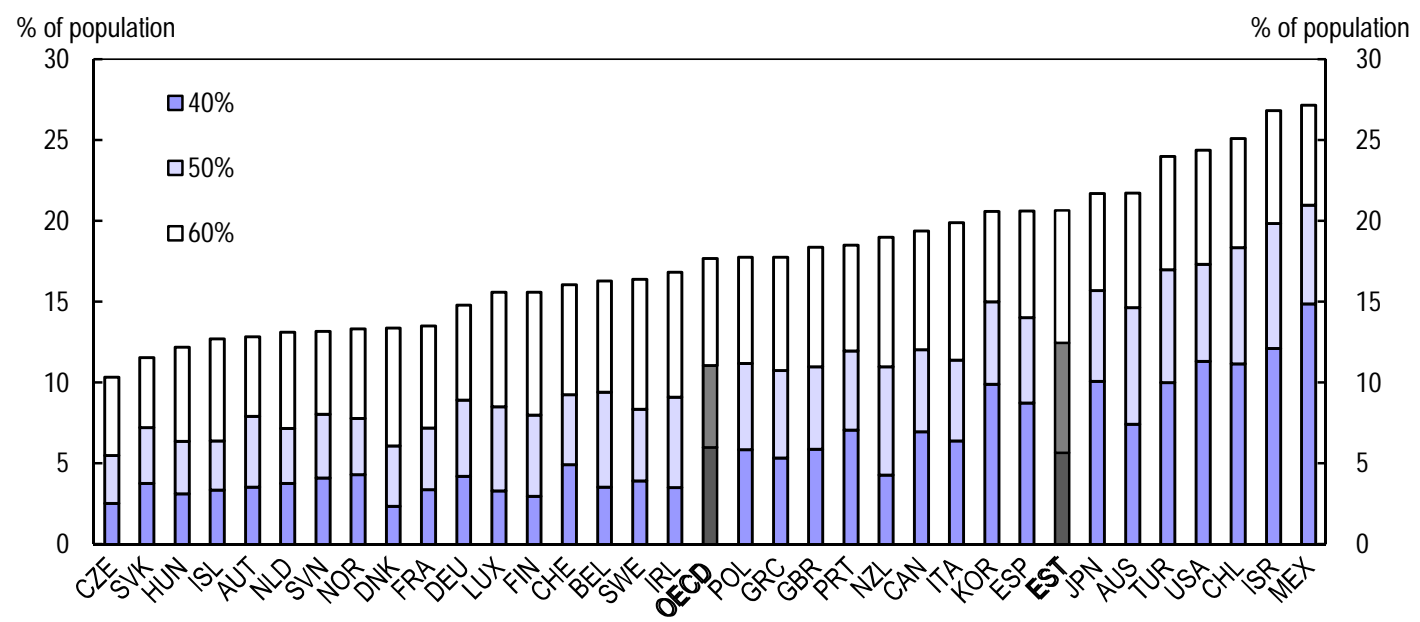

1. Measured as the share of individuals with disposable income adjusted for household size after transfers and taxes less than 40 , 50 and $60 \%$ of the median for the entire population.

2. Data refers to 2008; 2006 for Japan, 2007 for Denmark, Hungary and Turkey; 2009 for Canada.

Source: OECD Income Distribution-Poverty database.

Income inequality is substantially higher than in a number of continental European countries. The gap in the standard of living of the poorer parts of population can be illustrated by comparing poverty in

1. Artur Radziwill is a Senior Economist in the Economics Department of the OECD. Sarah Flèche is a graduate researcher at the Paris School of Economics. This paper was originally produced for the 2012 OECD Economic Survey of Estonia and published in October 2012 under the authority of the Economic and Development Review Committee (EDRC) of the OECD. The author would like to thank the Estonian authorities, as well as Andrew Dean, Bob Ford, Andreas Wörgötter, Lilas Demmou, and members of the EDRC for valuable comments and discussions. The paper has benefited from valuable background research by Bogdan Zaman. The author would also like to thank Seung-Hee Koh, Corinne Chanteloup and Margaret Morgan for statistical assistance and Josiane Gutierrez and Pascal Halim for secretarial assistance. 
Estonia at the fixed EU-wide threshold of EUR 10 per day, respectively, adjusted for purchasing power parity. In such comparison, and even prior to the crisis, Estonia had one of the highest rates of poverty in Europe, with about $15 \%$ of persons living on less than EUR 10 a day compared with less than $1 \%$ in Finland (Lelkes and Zolyomi, 2008). Using an EU-wide poverty indicator is problematic because of the interaction with general income differences (Fusco et al., 2010), which are mainly explained by still sizable productivity gap which can be only closed by more knowledge and innovation driven growth (Price and Wörgötter, 2011). However, in the case of Estonia and Finland this comparison may be justified, because of the close relation between the two countries. A high perceived poverty risk might be relevant for subjective well-being assessments, which can also be influenced by high income and unemployment volatility (Box 1). In this respect, Estonians are among the nations reporting the lowest life satisfaction, even controlling for the relatively low income per capita (OECD, 2011a).

\section{Box 1. Volatility and well-being}

Macroeconomic fluctuations entail important consequences for well-being. In recent years, a large body of theoretical and empirical research has examined the determinants of household satisfaction with the financial situation, income, job and life as a whole. One important finding is that economic insecurity and greater unemployment volatility significantly undermines perceived well-being (Wolfers, 2003; Sjoberg, 2010). An empirical analysis was carried out using both country panel macrodata and individual microdata to better understand what drives self-reported satisfaction in OECD European countries and identify the impact of macroeconomic volatility on Estonia's well-being, based on methodology described in Flèche et al. (2011). The regression results confirm that macroeconomic volatility significantly undermines life satisfaction, also in Estonia, even when controlled for other key determinants of well-being, including self-evaluated health, education, income and employment status (Table 2.1, Annex 2.2). While volatility in unemployment does not have significant impact in any specification, being unemployed strongly decreases life satisfaction, more in Estonia than in other OECD European countries.

Table 1. Regression results: determinants of life satisfaction1

\begin{tabular}{lccc}
\hline & $\begin{array}{c}\text { OECD countries } \\
1996-2008\end{array}$ & $\begin{array}{c}\text { OECD countries } \\
1996-2008\end{array}$ & $\begin{array}{c}\text { Estonia } \\
1996-1999-2008\end{array}$ \\
\hline & Macrodata & Microdata \\
\hline Mean life satisfaction & & Life satisfaction \\
\hline Household disposable income & & $0.280^{*}$ & $0.538^{*}$ \\
Household disposable income & $0.116^{*}$ & $(0.014)$ & $(0.085)$ \\
standard deviation & $(0.047)$ & $-0.006^{*}$ & $-0.005^{*}$ \\
Unemployment rate & $-0.010^{*}$ & $(0.000)$ & $(0.000)$ \\
& $(0.003)$ & $-0.043^{*}$ & $-0.065^{*}$ \\
Unemployment rate standard & $-0.119^{*}$ & $(0.003)$ & $(0.003)$ \\
deviation & $(0.022)$ & -0.003 & -0.017 \\
Perceived income inequality & 0.017 & $(0.009)$ & $(0.012)$ \\
Being unemployed & $(0.065)$ & $-0.016^{*}$ & $-0.045^{*}$ \\
& & $(0.003)$ & $(0.013)$ \\
\hline Observations & & $-0.489^{*}$ & $-0.725^{*}$ \\
\hline R-squared & & $(0.038)$ & $(0.150)$ \\
\hline
\end{tabular}

Note: Robust standard errors in parentheses, ${ }^{*}$ denotes significantly different from zero at $5 \%$ level.

1. List of control variables and full specification in the Annex 2.A2.2.

Source: Annex 2.A2.2. 


\section{Working-age poor were hit hard in the crisis}

In the crisis, the working-age poor were hit particularly hard (Figure 2). The impact is less visible in the aggregate relative poverty rates (Annex 1) because the median income fell deeply for the whole population, but disposable incomes at the bottom of the distribution fell more than for higher income brackets. The share of population living in absolute poverty, i.e. with expenditures below the subsistence minimum increased from $6.5 \%$ in 2007 to $11.7 \%$ in 2010 . A similar increase in relative poverty measured at the unchanged threshold confirms that this was not a result of methodological changes (Statistics Estonia, 2012). The youth were most strongly hit. This is consistent with international evidence showing that negative macroeconomic shocks tend to have a regressive impact on the income distribution, and on the youth in particular (Ahrend et al., 2011). This is because the earning volatility is highest for young, male and low skilled workers, often with non standard work contracts, or self-employed, who face the highest risk of income loss and have a weak attachment to the social insurance system and little resources for self-insurance (OECD, 2011b). The impact on households with children was lower than on average, partly because of family support policies (Statics Estonia, 2012). However, the absolute poverty among children increased substantially from $9.4 \%$ to $18.1 \%$ (Figure 2). Not surprisingly, those losing jobs suffered the most, as households without work are at a very high risk of poverty, while those working at lower wages were hit less hard (Statistics Estonia, 2012). Also survey responses confirm that households at the bottom of income distribution reported most often a loss of life satisfaction between 2006 and 2010 (EBRD, 2011). 
Figure 2. Economic crisis had a strong negative impact on the poor

A. Incomes at the bottom have been hit hardest

Household disposable income, real change \%, 2008-2010

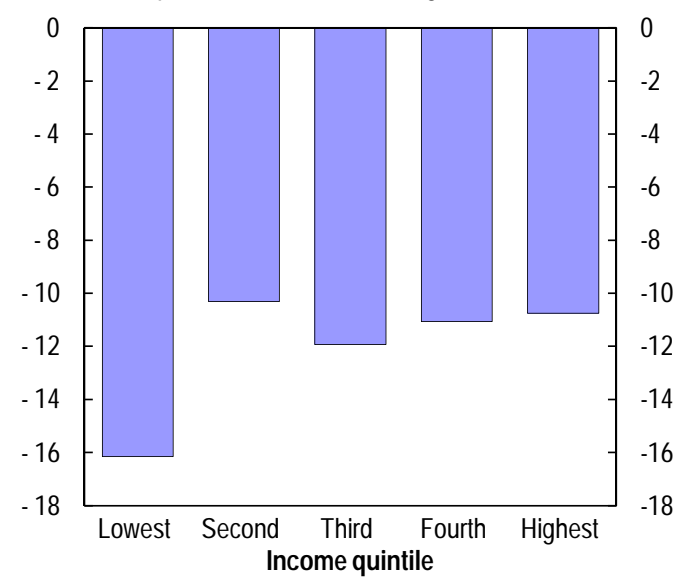

C. Lower income households report the biggest hit on life satisfaction

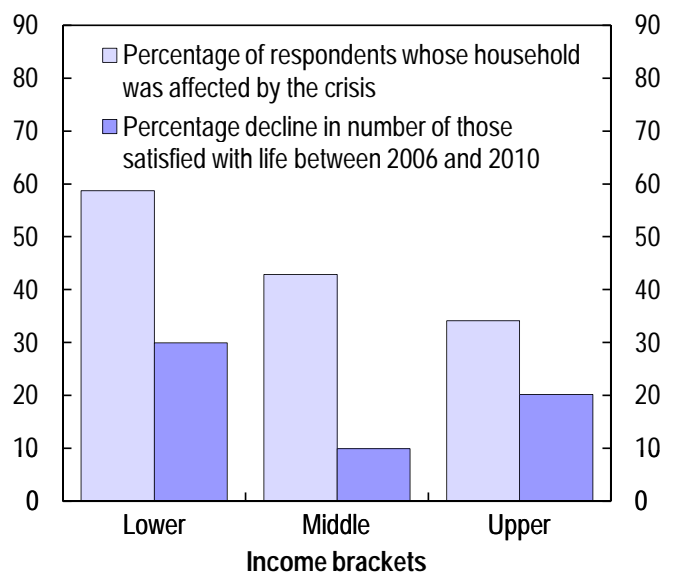

\section{B. Absolute poverty increased sharply}

Share of household members under absolute povery line ${ }^{1}$

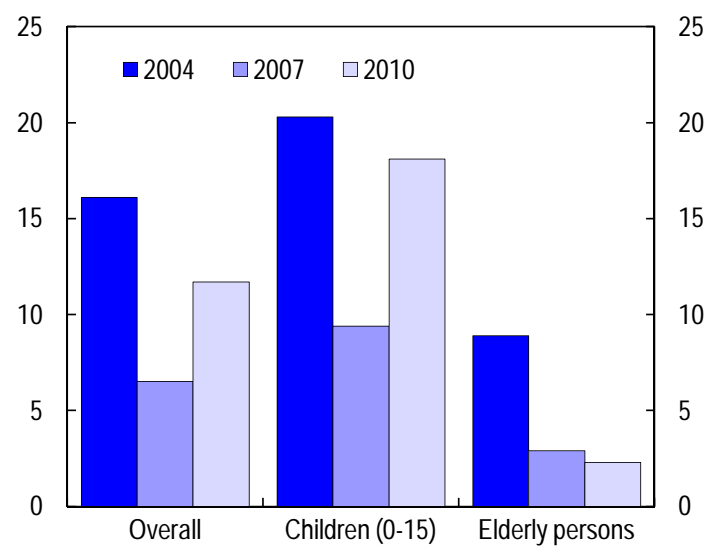

D. Poverty among those without work is very high

\section{$\%$ of persons with a household disposable income lower than the at- risk-of-poverty threshold²}

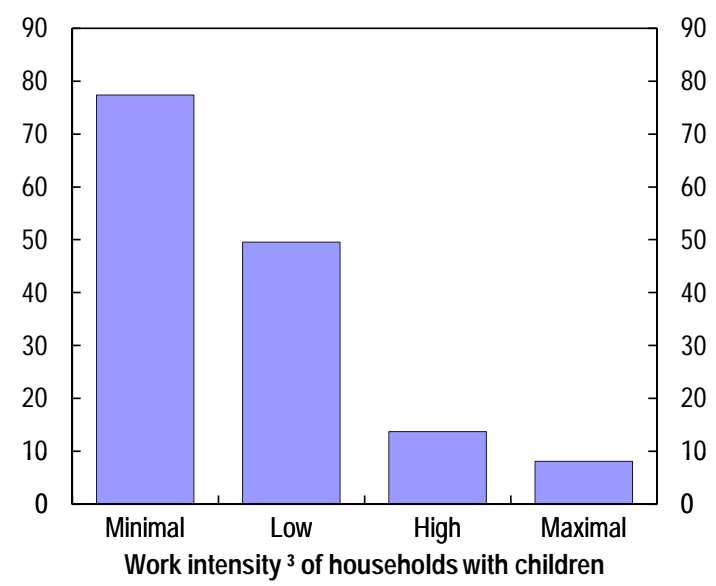

1. Absolute poverty line is calculated by Statistics Estonia on the basis of three components of expenses: food, housing and non-food needed to maintain the minimum level of welfare. Data for 2010 is not directly comparable to the previous data due to the methodological change in 2010.

2. The at-risk-of-poverty threshold is $60 \%$ of the median disposable income adjusted for household size.

3. Work intensity in a household is the number of months spent by working age household members (aged 16-64) in employment or self-employment divided by the maximum number of months which could have been worked.

Source: EBRD-World Bank, Life in Transition Survey 2010, LiTS II; Statistics Estonia; and Estonian Social Survey.

\section{Strengthening activation and targeting income support}

While poverty risk is high, Estonia stands out in international comparison in terms of low social spending, including that directed at the working-age population (Figure 3). This reduces the scope for poverty and inequality reduction. Social transfers other than pensions reduced the share of population at-risk-of-poverty from 25 to $16 \%$, which is one of the lower reductions across European OECD countries (EU-SILC, 2012). The measured inequality is not only one of the highest in Europe, but also the impact of transfers and taxes on reducing inequality is among the lowest in the EU (Figure 3). 
Figure 3. Transfers (other than old-age pensions) are small and untargeted with limited impact on inequality

A. Public cash transfers (other than old-age pensions) to household, \% of GDP, 2007

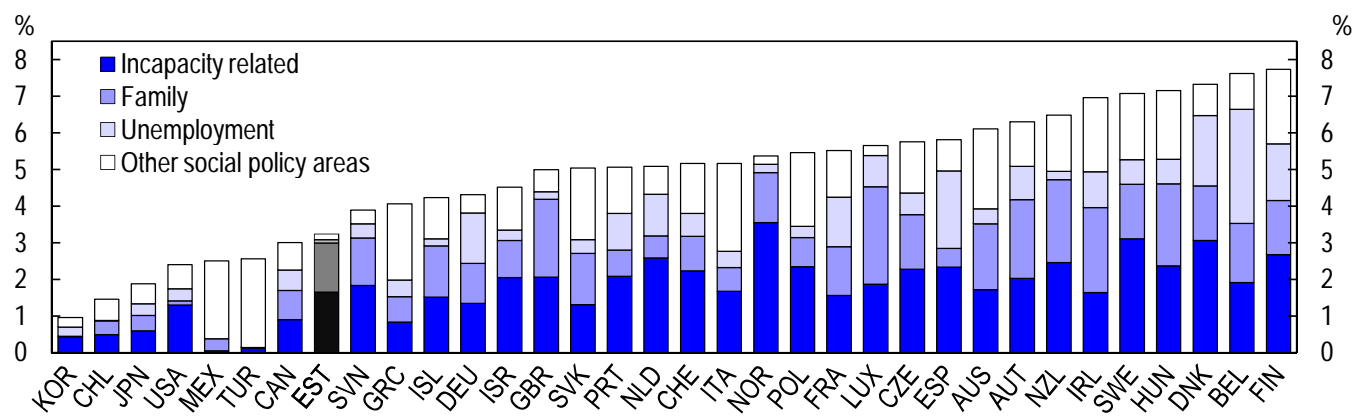

B. Impact of taxes and transfers (other than old-age pensions) on income inequality, percentage point reduction of Gini coefficient, 2007

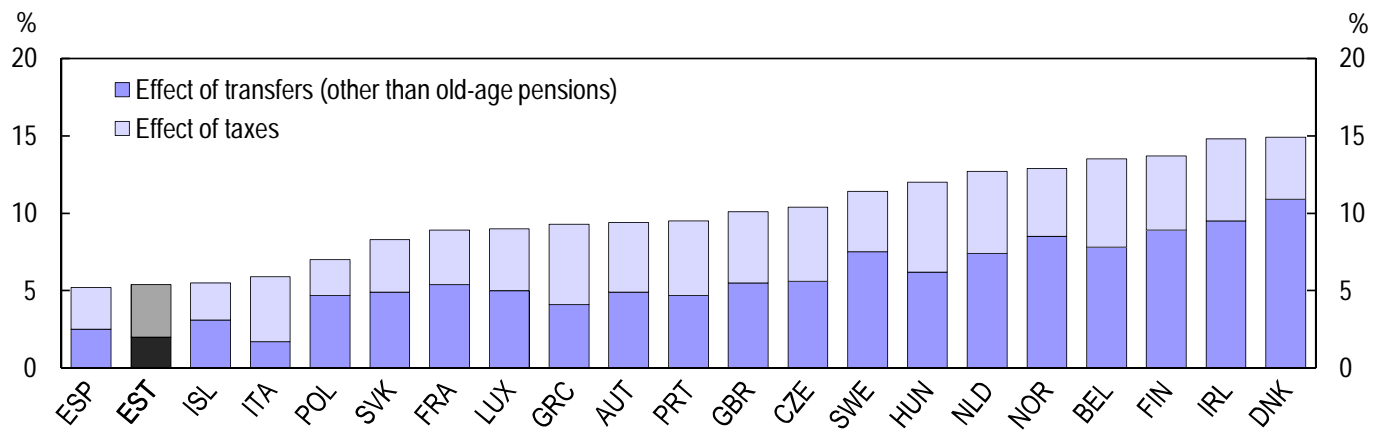

Source: OECD Social Expenditure database; Eurostat(2010), Income and Living Conditions in Europe, Table 16.1B.

Social spending for the working-age population is not only low, but also its structure is biased against short-term income support schemes (Box 2), as the large majority of spending is directed at family and disability policies, and the share of unemployment support and social assistance is very small. This reflects a social policy stance that is focused on self-responsibility and work incentives, and deemphasizes the role of redistribution. Although these principles may result from social choice, the low level of short-term income support means that the poverty among those without work is among the highest in the European Union (Figure 4), with $70 \%$ of households without work at the risk of poverty, while employment losses in the crisis were also the highest.

Box 2. Two tier unemployment protection and social assistance

Unemployment insurance provides contribution-financed and earnings-related benefits. The benefit is available to registered unemployed who have contributed for at least 12 over the last 36 months to the Unemployment Insurance Fund. Voluntary job separations and separations due to poor performance are not covered. The benefit is $50 \%$ of the previous wage during the first 100 days of benefit period and $40 \%$ thereafter. The minimum benefit is fixed at half of the previous calendar year minimum wage, the maximum at 1.5 times the previous year's average wage. The maximum benefit duration is 180 days if the contribution period is less than 56 months; 270 days if it is between 56 and 110 months and 360 days if it is higher than 110 contribution months. No supplementary income from work is allowed. An eventual severance pay has to be consumed before the unemployment insurance benefit can be collected.

Unemployment assistance is a flat rate non-contributory benefit that is financed by the general budget and addressed to those unemployed who are not eligible for the insurance benefit or have exhausted their unemployment insurance entitlement. A claimant has to work or study full time for at least 180 days during 12 months prior to registration. Unemployment assistance is available in cases of unemployment after voluntary job quits and job separation because of bad performance. The maximum duration of unemployment assistance is 270 days, or 210 days following voluntary quits. The size of the benefit is fixed annually in the budget and has stood at EUR 64 per month 
since 2008. It is planned to increase it to the $50 \%$ of minimum wage in 2013 , which means more than doubling it. Other income is allowed up to the size of the unemployment assistant benefit.

The subsistence benefit is a support to needy persons, paid by a local municipality, to bring incomes to the minimum subsistence level. It is financed from the general budget. The subsistence level is established by Parliament each year and is calculated to cover minimum expenditure for consumption of food, clothing, footwear and other goods and services, after payment of housing costs. Housing and heating costs are also covered up to the limit fixed by each municipality. Municipalities can also decide to pay additional subsistence benefit over and above the centrally determined level. For example, the high costs of pharmaceuticals can be compensated, or fees for services such as day-care can be waived.

Figure 4. The poverty among unemployed is among the highest in the EU

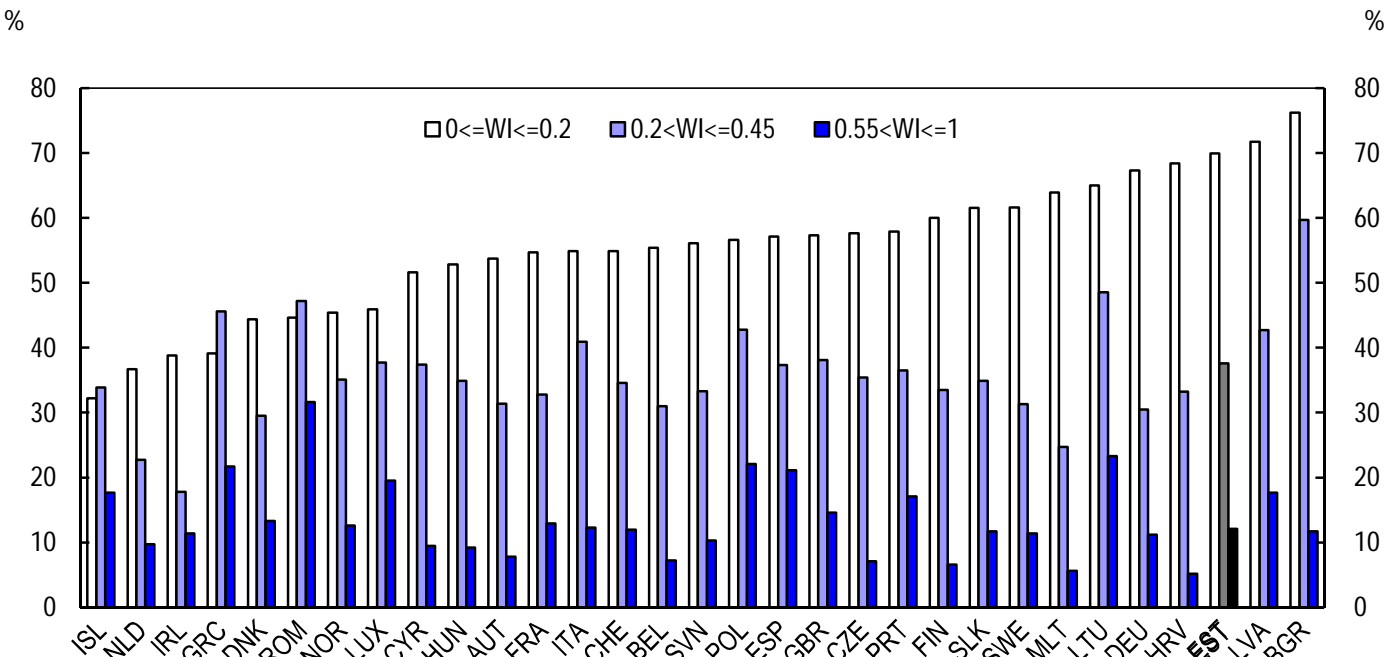

1. At-risk-of-poverty rate is share of persons with an equalised yearly disposable income lower than the at-risk-of-poverty threshold.

2. Work intensity (WI) in a household is defined as the total number of months spent household members in employment or self-employment during income reference period relative to the maximum number of months the household members could have spent in employment or self-employment. This indicator ranges from zero (no working age member worked) to one (all working age members worked throughout the income reference period).

Source: EU-SILC 2012.

While high economic volatility involves a high rate of job destruction, elements of flexicurity can help overcome the tension between aggregate economic adjustments and limit the negative impact on individuals (Ahrend et al., 2011; OECD, 2011b). It is achieved by enabling employability and protecting the most vulnerable rather than preserving jobs themselves. This has been the guiding principle of labour market and social policy reforms across OECD countries, guided by the OECD Jobs Strategy (OECD, 2006). Temporary income support is needed, as some employment shocks are large and low earners have little opportunity for self-insurance (Ahrend et al., 2011). In Estonia, very limited income support restricts cash-poor households from more effective job search and making better employment choices. Similarly, access to active labour market measures may be hampered. In Estonia, the increase in the number of persons who are willing to work and available for work, but who do not search actively for a job was among the highest across OECD countries (OECD, 2012a).

Designing short-term income-support schemes is not easy, because they have negative effects on incentives, potentially leading to a trade-off between short-term poverty reduction and risks of long-term deactivation, (Ahrend et al., 2011). This is less of a problem in Estonia since benefits there are currently so low that they usually do not pose large disincentive effects. Moreover, examples of Nordic and other countries demonstrate that the trade off is actually not as steep as one might think, and it is possible to 
combine high employment rates with strong poverty mitigation policies (Figure 5). In contrast, Estonia is currently in the group of countries with high employment and poverty rates. Reducing poverty while maintaining and improving positive employment outcomes requires, however, that any increases in benefit generosity are supported with a further step up in activation policies.

Figure 5. There is scope to simultaneously lower poverty and increase employment

Level of employment and poverty, 2008

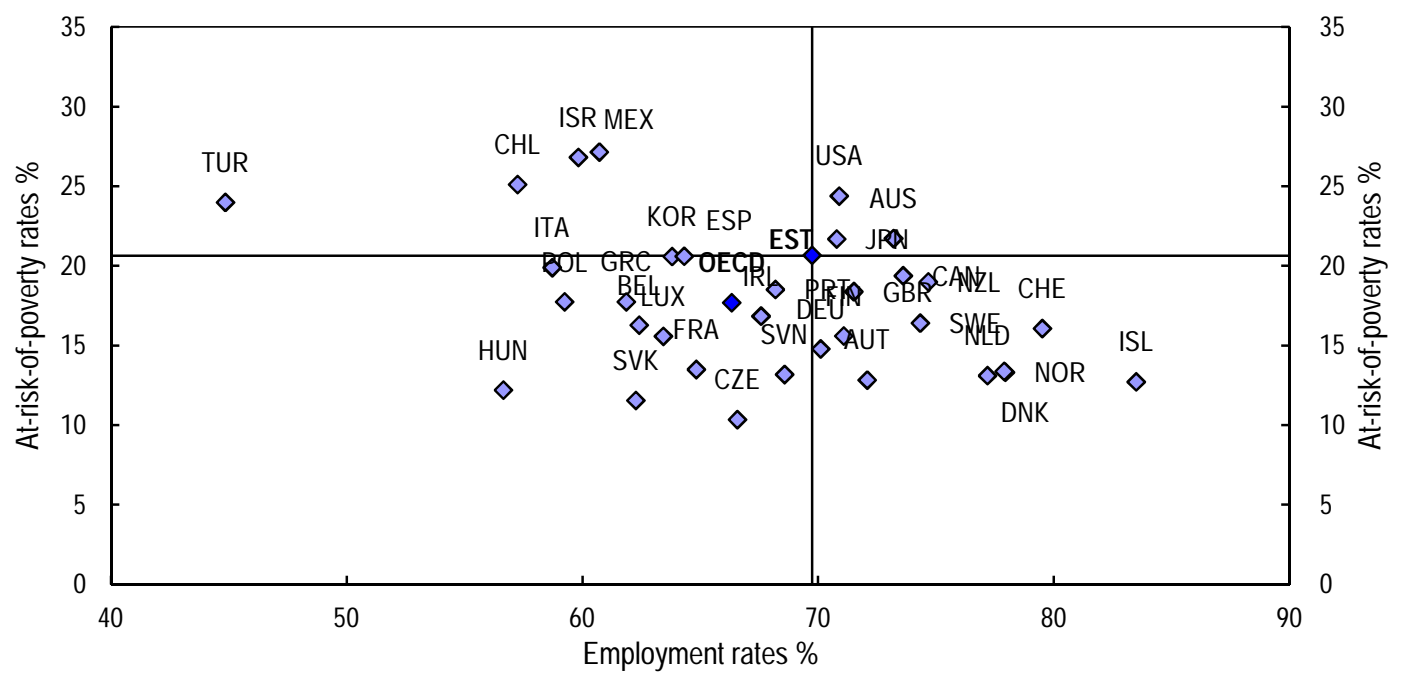

Note: Latest poverty data refer to 2008 for the majortity of countries; 2006 for Japan; 2007 for Denmark, Hungary and Turkey; 2009 for Canada.

Source: OECD Labour Force Statistics database and OECD Income Distribution database.

\section{Increasing activation role of social system}

As only $50 \%$ of registered unemployed receive unemployment benefits, the risk of poverty due to unemployment is in practice addressed by other benefits, where gatekeeping is weaker. These other benefits are frequently sought by individuals who were not eligible for, or have exhausted their unemployment benefit entitlements. The current policy set-up therefore contributes to the outflow of individuals from unemployment benefit, the only social programme with strong activation, to programmes which do not provide sufficient activation and skill-enhancement opportunities, potentially generating longer-term dependence (Praxis, 2011). In particular, disability in its current design is the benefit of last resort for many, and is provided without restrictions for work income. However, it is not allowing employed workers with some disability access to any activation measures, and so without perspectives for better utilising the remaining work capacity. Activation of subsistence benefit recipients is also weak.

Spending on disability and sickness benefit actually dwarfed unemployment support prior to the crisis, and the ratio between these two categories was much higher in 2007 than the OECD average (Figure 2.6). Estonia is scoring very unfavourably in terms of self-reported disability prevalence (OECD, 2010a; Figure 1.1). This means that there is a large pool of potential disability benefit applicants. It underscores the importance of stepping up the promotion of healthier lifestyles, prevention, and rehabilitation. Once on a disability benefit scheme the risk is that without proper activation measures the remaining work capacity will not be fully utilised, meaning an avoidable income loss and higher poverty risk. 
Figure 6. Ratio between spending on disability and unemployment is high

Ratio of expenditure on disability and sickness to unemployment benefit spending, 2007

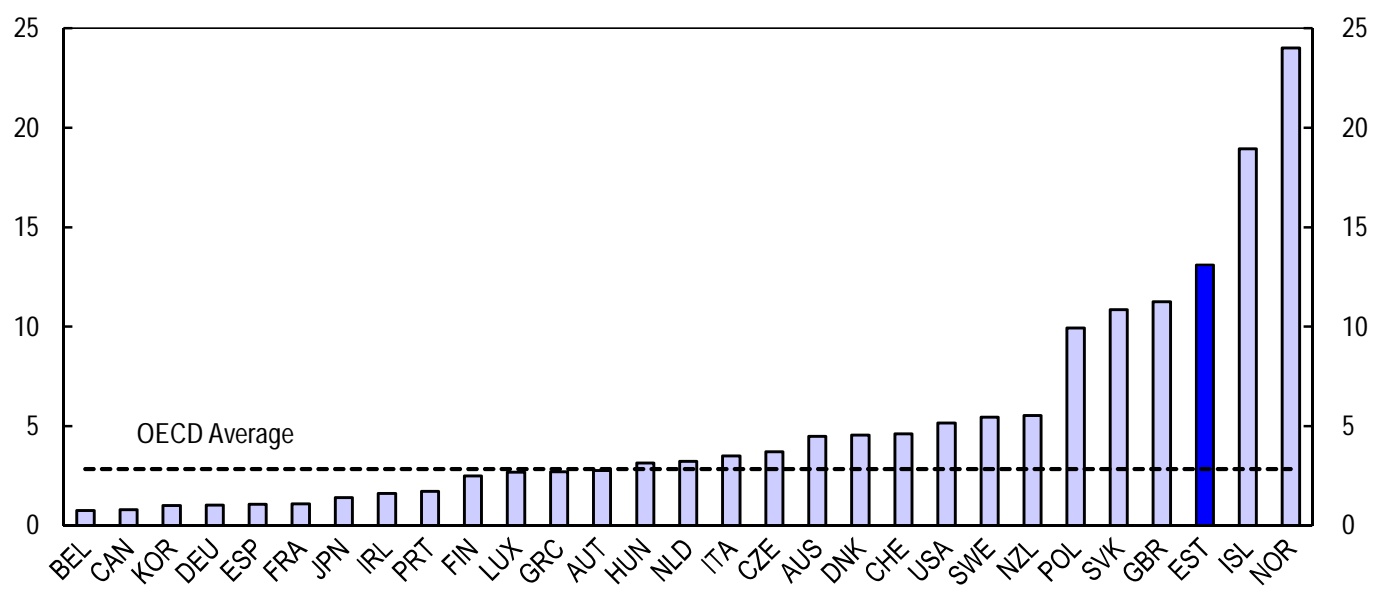

Note: Disability refers to public and private disability pensions; sickness refers to public and private paid sick.

Source: OECD (2010), Sickness, Disability and Work, Table 2.1 and Social Expenditure database.

Moving towards a more integrated approach to activation and social policies is therefore an important challenge. Passive and active policies are only strongly linked together in the case of unemployment benefits. But important other benefits for the working-age population are in fact playing a role of compensating work income losses, but doing this without activation measures. Countries like Germany have made good progress with broadening the access to activation measures, together with a job search obligation, for all unemployed and inactive with some remaining work capacity (OECD, 2010c). The ambition in Estonia should be the same. In the short run, all benefit programmes for working age population with some remaining work capacity, should be linked to job search requirements if not already working and being offered the full catalogue of ALMPs in order to improve the income from the remaining work capacity. Activation should therefore become an important element of programmes addressing sickness and disability, and its role should be strengthened in the case of subsistence benefit. Family support can also be more directed at employment promotion, in particular through improving the availability of child care institutions. The additional costs of extending activation policies widely might seem high, especially when added on top of existing passive spending. However, it is important to consider the full costs of long-term unemployment and underutilisation of work capacity, possible deactivation and human capital depreciation, including the net present value of lost taxes and additional social transfers.

\section{Reducing fragmentation of social policies}

Strengthening activation is complicated by the fragmentation of social policies that makes it more difficult to case-manage individuals. There are currently several interlinked programmes and schemes, operated by different institutions, and their cooperation is far from perfect. The unemployment insurance fund, social insurance fund, health insurance fund, municipalities and vocational education establishments all play essential roles in providing support to individuals who could benefit from activation, but who are now shifted across schemes or can be clients of several institutions at the same time. The unemployment insurance fund, which should be the centre of activation-based social policies, is not connected well enough with other parts of the system. In the long term, a one-stop shop for all clients with some capacity to work should be created and make referrals to different service providers. In the short run, it is important to swiftly conclude analysis phase to prepare internet-based e-services. In reforming the system, the limited human and material resources of the municipalities need to be recognised (Box 3), and incentives need to be put in place to encourage enough cooperation among municipalities as well as other institutions to provide efficient services provision, including through experimentation with multi-service cooperation 
over a broad territorial area, even while more fundamental sub-national administrative reform is politically difficult to implement (OECD, 2011c). Establishing national minimum service standards would also be important to ensure both more equal access and the quality of social services (NAO, 2010a), and should be underpinned by some adjustments to the equalisation grant and block grant system (Smidova, 2011).

\section{Box 3. Increasing municipal capacity to provide social services}

Increasing the capacities of municipalities and improving the quality of municipal spending is an important challenge, not least for increasing the effectiveness of activation and social protection (OECD, 2011c). Estonian municipalities are in charge of a wide variety of tasks. The largest spending item is primary and secondary education, followed by culture and leisure, social services, and housing services, as well as municipal transport in bigger cities. Some services are financed by the state budget, others are covered form own budgets. In the crisis the revenues of local government declined by $15 \%$ on average between 2008 and 2010 with a considerable variation among municipalities, including a one third fall in the most badly affected municipalities. In response, the municipalities tended to postpone investments and infrastructure spending, while protecting health, education and social services. Indeed, local governments' expenses on social benefits have grown during the economic crisis, while overall expenditures decreased. Many municipalities increase services targeted at the very poor, often in cooperation with non-governmental organizations and often on an ad hoc basis, including free meals, clothing, and shelters for homeless people. However, according to the survey of local governments, municipalities still spent on average over $70 \%$ of the total expenses of social benefits on non-means-tested benefits (Kriisk, 2012).

There are equity concerns about the uneven level and quality of public services across municipalities (OECD, 2011c). All municipalities are in principle expected to provide the same basic services. However, municipalities vary greatly in population size and wealth. In particular many of municipalities are very small, as there are 226 elected local governments. While the average size of municipalities is several times smaller than in Nordic countries, half of the municipalities have a population of under 2000 inhabitants. There are very large difference in municipal expenditure per capita, which varied between EUR 510 and EUR 2690 in 2009, and in types of local social benefits that are being provided. Moreover, the poorest municipalities tend to face the highest social protection needs, while they have very limited fiscal, administrative and service delivery capacity. Detailed analysis of municipal spending patterns shows that while almost all local governments allocate some social benefits for those 'in-need', almost half of them have never clearly defined the criteria for such assistance (Kriisk, 2012). Many local governments do not even keep detailed accounts of the costs of various local social benefits and services.

\section{Strengthening targeting}

Another important characteristic of social policy in Estonia is the low share of means-tested transfers (Figure 7). This means that support is spread thinly, with much being spent on supporting more affluent families. This assessment is confirmed by an analysis of the distribution on transfers (other than old-age pensions) and taxes among income groups, and the contribution they make to the disposable incomes of households in these groups (Figure 8). Subsistence (housing) benefits are very well targeted, as about $75 \%$ of transfers are directed at households in the first quintile. However the very small size and coverage, which translates into overall spending of only $0.1 \%$ of GDP in 2011, means that its importance for aggregate disposable income at the bottom of the income distribution is small. Disability benefits are effectively quite well targeted at the poorest parts of population, with $40 \%$ of spending going to households in the first income quintile, and because of the wide coverage and aggregate size of $1.5 \%$ of GDP, it makes a visible difference to average incomes of the bottom quintile. In contrast family benefits, which amount to around $1.3 \%$ of GDP, have a rather regressive character, as the largest share goes to the top income quintile due to generous maternity and paternity replacement rates. The same is true of unemployment insurance benefits (spending on income-tested unemployment assistance at $0.04 \%$ of GDP is small compared to 
unemployment insurance benefit at $0.2 \%$ of GDP in 2011). At the same time, these two programmes represent only a small share of income for the top quintile. In aggregate, transfers other than old-age pensions are almost equally distributed among income quintiles, and hence provide little redistribution. In fact in Estonia such transfers are the second least distributive in the EU (Atta-Darkua and Barnard, 2010). Even the flat income tax rate system provides higher degree of redistribution. In sum, the tax-benefit system contributes relatively little to the reduction of inequality and poverty among working-age population.

Figure 7. The size of spending on income-tested programmes is the lowest in the OECD

Public social expenditure on income-tested programmes, \% of GDP, 2007

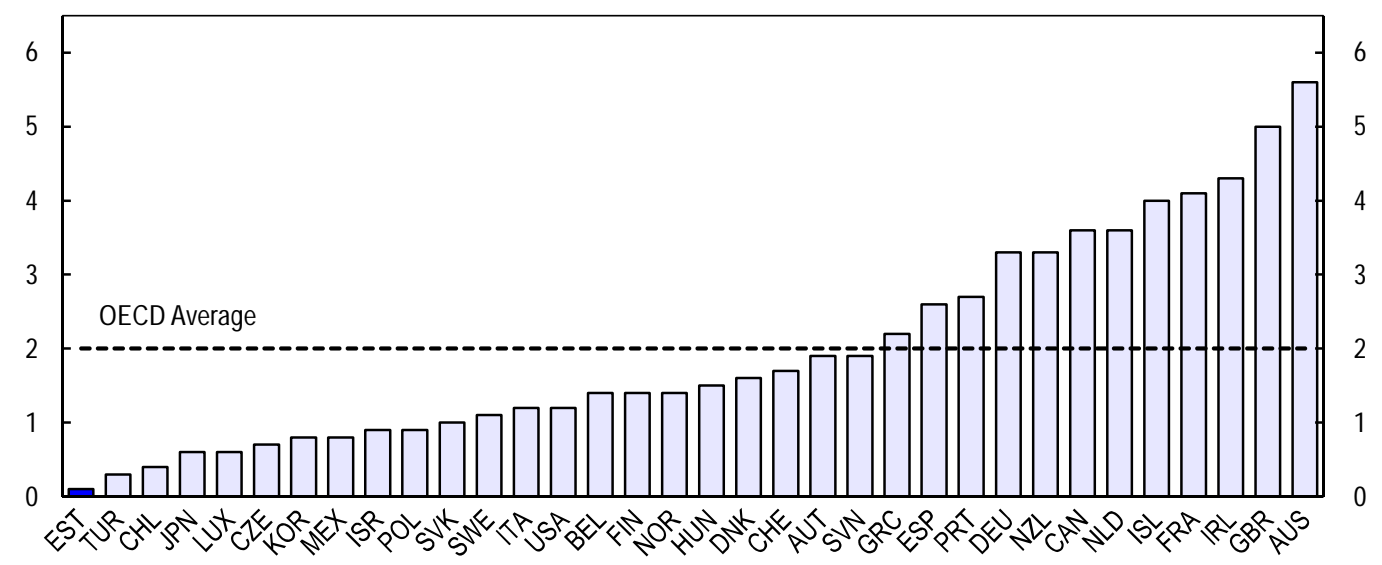

Source: W. Adema et al. (2011), OECD Social, Employment and Migration Working Paper No. 124, Table I.1.

Better targeting of both benefits and services could be another element in making the social protection model more successful at reducing poverty at relatively low cost. The experience of several countries, including emerging countries, suggests that problems in implementing targeting can be overcome and that investing in better means-testing, including proxy mean-testing, is worthwhile (OECD, 2011b). Relatively high administrative capacity and high IT sophistication in Estonia provide good foundations for such investments (OECD, 2011c). To minimise the problem of undeclared work, as well as to maintain good work incentives, it might make good sense to use non-income testing, including material deprivation and asset wealth, as is usually done under targeted social protection schemes in advanced economies. Including financial asset, real estate and car ownership in means-testing would be among the first and obvious steps in this direction. More generous assistance could also be directed to certain groups with weaker ability to adjust, including single parents and families with many children. 
Figure 8. Disability is the only large transfer program that redistributes to the poor

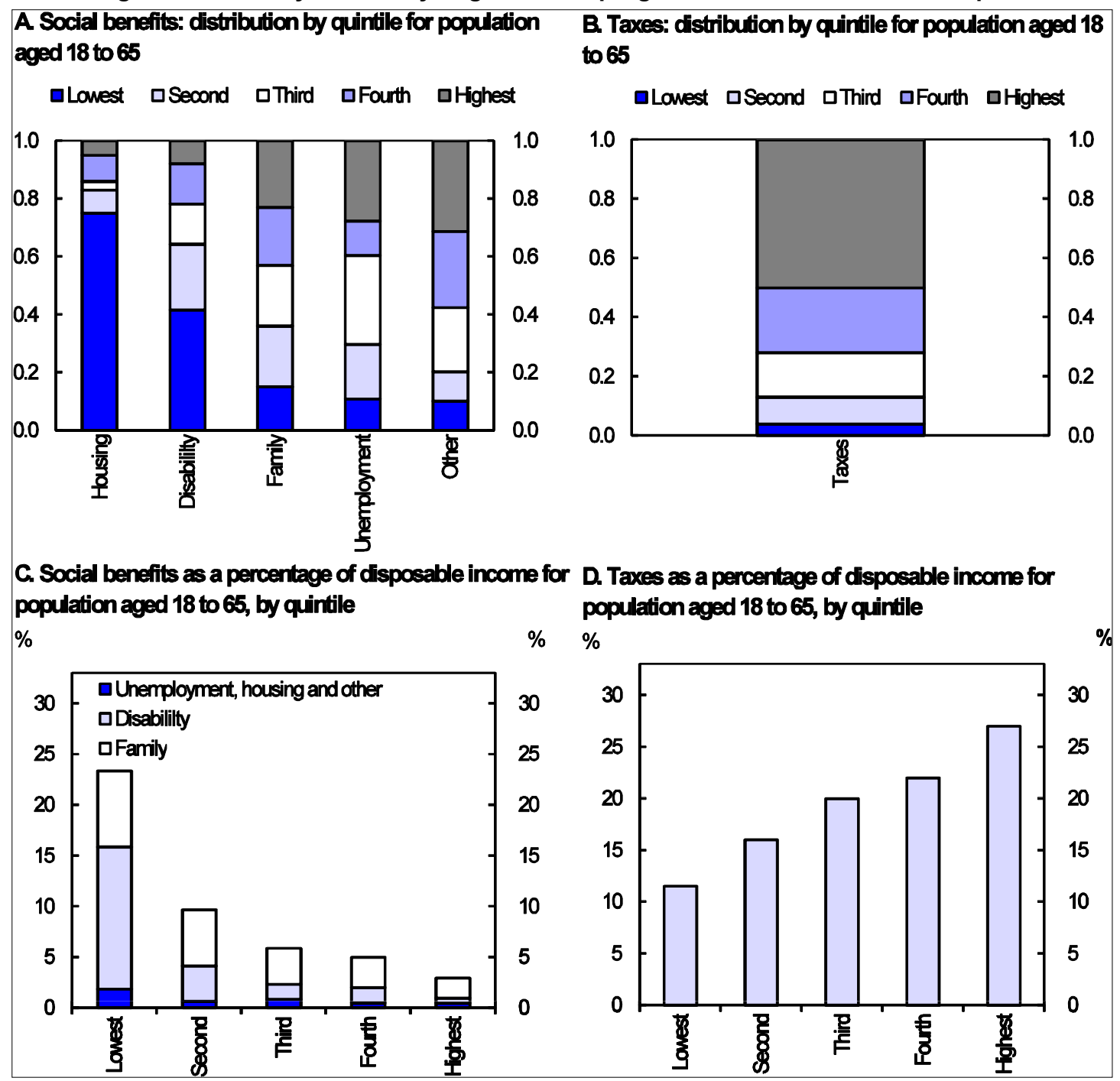

Note: How to read the figure: According to Panel A, 15\% of total spending on family benefits are received by households in the first quintile in terms of disposable income adjusted for household size. According to Panel C, family benefits accounted for $7 \%$ of disposable income of the average household in the same quintile.

Source: OECD (2010), Reviews of Labour Market and Social Policies: Estonia, Table 3.A1.2.

\section{Reforming the disability system to promote the earnings capacity}

Almost $10 \%$ of the labour force in Estonia receives a disability-related pension or benefit (Box 4), compared to $6.6 \%$ in the OECD on average (Figure 9). The number of people receiving a pension for work incapacity increased by three quarters between 2001 and 2010, and the number of those receiving a disability allowance increased by almost $40 \%$. This rate of increase of disability-related entitlements is among the highest across OECD countries. The social and economic costs of this trend may become substantial, although current spending is still below OECD average. Even though a relatively high share of the disabled is working, disability reduces the return on human capital without proper rehabilitation and requalification measures $(\mathrm{OECD}, 2010 \mathrm{a})$ and comes on top of the burden of a labour force that is already shrinking at high speed due to demographic trends. Disability is also associated with higher unemployment and inactivity, which is bad for one's health, in particular mental health, while returning to work is usually associated with improved health (OECD, 2010a). Doctors report that preparing documents for disability is actually a major distraction from treating people (NAO, 2010b). 


\section{Box 4. Incapacity to work, disability and sickness}

There are two ways of defining invalidity in Estonia, disability and incapacity for work. A person of working-age can be disabled, incapable for work, or both at the same time. The determination of the degree of disability is independent from the determination of incapacity for work, although the two assessments are usually done simultaneously. Correspondingly, there are two parallel schemes offering invalidity-related support.

Permanent incapacity is assessed as total if a person has a serious functional impairment caused by an illness or injury, due to which he or she is not able to work. It is assessed as partial (10-90\%) if a person is able to work but is not able to perform a suitable job to full extent. Incapacity pension is paid by the social insurance fund in case of $40-100 \%$ loss of work capacity, and its size is calculated as a respective percent of the full old-age pension entitlement, which is linked to the contribution record. By definition this benefit is only paid for persons with a minimum employment career.

Disability can be moderate, profound or severe, depending on the degree of restriction on daily activity or participation in social life. Disability benefits are paid out of the state budget at flat rates dependent on the intensity of restrictions on daily activity and participation in social life. The purpose of the benefit is to cover additional expenses to overcome these restrictions, including expenses on medical products, transport, maintenance of medical devices, personal care and household management, use of the means of communication, clothing and footwear.

Work is allowed under both schemes and neither the size of the disability benefit nor the incapacity pension is dependent on own sources of income. In 2011, expenditures on incapacity pensions at around $1.3 \%$ of GDP were almost four times larger than those on disability benefits, with total below the OECD average but with the rapid growth rate. Both benefits are granted on a temporary basis, although positive re-assessments are very rare.

The maximum period of sickness benefit is 6 months, which is relatively restrictive by OECD standards. Expenses on sickness benefits actually fell dramatically after adjustment in the crisis when the sickness benefit replacement rate was reduced from $80 \%$ to $70 \%$ of salary, and own liability increased to 3 days, and for employers to 4 to 8 days.

Rapid increases in the number of benefit recipients are partly driven by powerful forces outside the disability system. Firstly, ageing contributes to deteriorating health in the population. The prevalence of self-reported disability in Estonia is the highest across all OECD countries, which is also a reflection of unhealthy lifestyles but also difficult working conditions during the communist times, although general health outcomes in Estonia have been systematically improving. Secondly, post-communist transition and skill-based technological change make old qualifications increasingly unfitted to new needs, and reduce the chance of low-skilled in the labour market. Increases in the retirement age and the closing of avenues to early retirement have made problems with changing skill requirements more visible and workers with difficulties in coping with these changes have increased the pool of applicants for invalidity-related benefits. This contributes to a higher share of people with lower education among the disabled.

Importantly, there are only limited alternative sources of income support for those in economic hardship. Entitlements for other working-age benefits are very tight and spending on disability-related benefits dwarf all other working-age income support programmes other than family benefits, notably unemployment and social assistance. Disability has therefore emerged as the benefit of last resort for parts of the working-age population. In practice, disability-related benefits play a strongly redistributive role, even though that was not enforced through means-testing. As many beneficiaries are working, benefits in practice also play the role of an in-work benefit. A surge in inflows happened during the crisis among those with a relatively high work capacity, where applications are most likely driven mainly by economic and not by medical factors. Inflows were particularly high in regions with the worst labour market outcomes. Males, who were more significantly affected by the recession, were overrepresented compared to usual patterns (Statistics Estonia, 2011). 
Figure 9. The number of permanent incapacity to work benefit recipients increased rapidly in the crisis A. Disability benefits recipiency rates, $\%$ of population aged 20-64

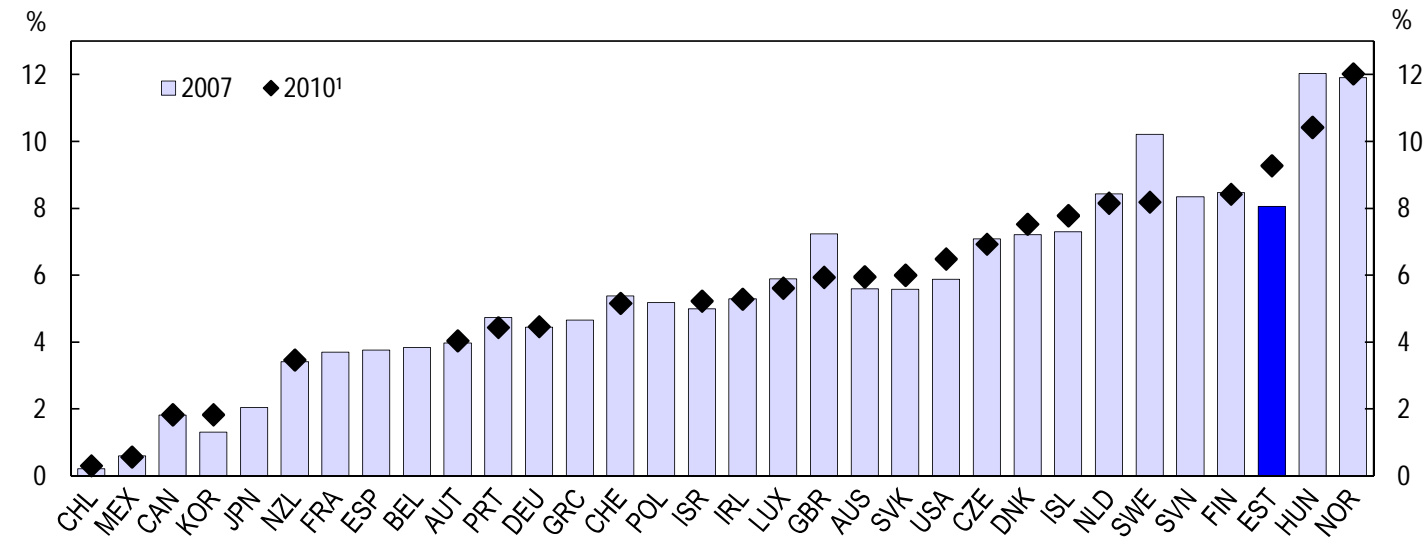

\section{B. Permanent incapacity for work}

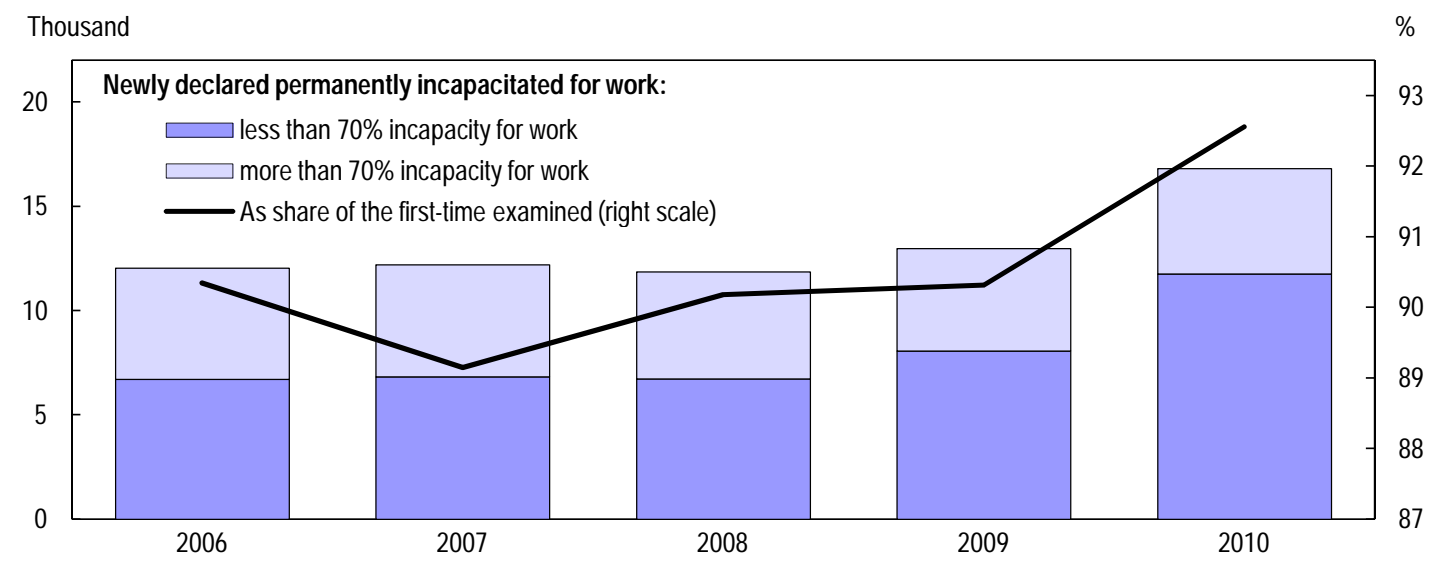

1. 2009 for the Czech Republic, Germany, Finland, Mexico, Norway, New Zealand, Switzerland and the United Kingdom.

Source: OECD (2011), Employment Outlook, Box 1.3; Statistics Estonia (2011), Statistical Yearbook of Estonia.

Income support through disability-related benefits has been found to imply high long term fiscal and social costs (OECD, 2010a). It is particularly inefficient in a highly volatile economy, when people should be expected to acquire new skills and facilitate structural change. In contrast, disability in Estonia does not include an explicit activation role, which aims at making most out of the remaining work capacity, and the only significant outflow from disability is towards the pension system (Praxis, 2011). So while costs of inflows into unemployment insurance are more visible in the short-term, the longer term burden of disability will be higher.

Spending on disability as a share of GDP is lower than the OECD average of $2 \%$ of GDP, mostly because benefits are generally low. More broadly, several aspects of disability compensation are fairly restrictive, at least on paper (Figure 10). Unlike in most other OECD countries, a 100\% disability level is necessary to claim the full benefit. Disability and incapacity status are both granted for a fixed term from 6 months to 5 years, which is among the most restrictive regulation in the OECD, even though it does not lead to actual exits from the system. The restrictiveness of disability benefit entitlements is only marginally lower than that of work incapacity pensions, but with benefits rates much lower in international comparison. However, high inflow and low outflows remain the main problem of the system. 
Figure 10. Disability system is not generous, but does not promote outflows

A. OECD disability policy typology, country scores (0-50), around $2007^{1}$

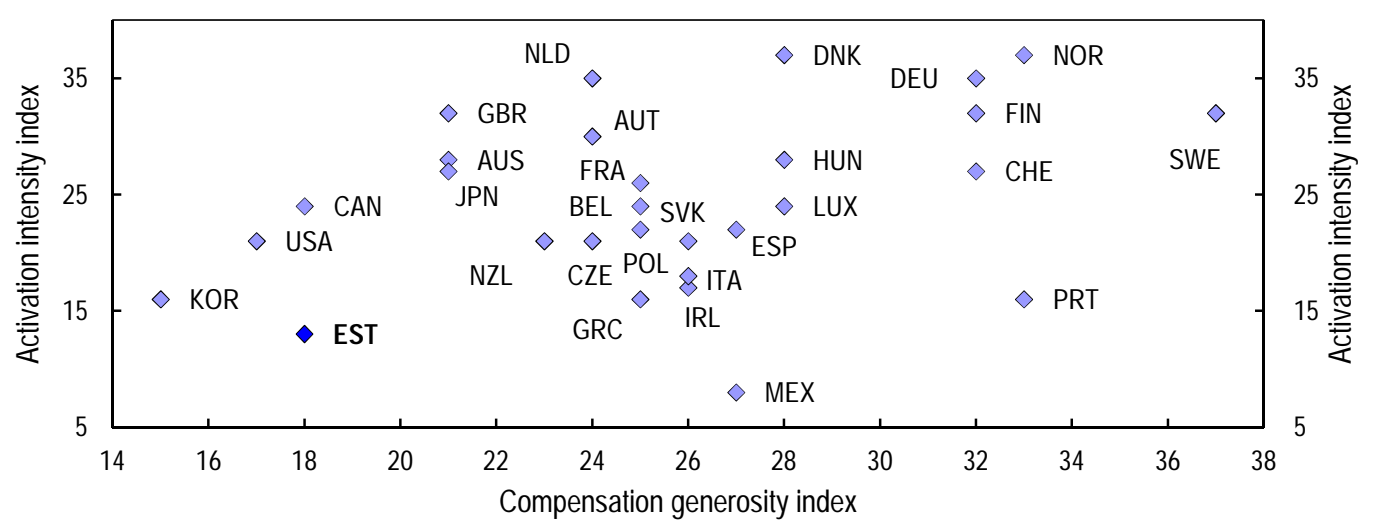

B. Generosity of compensatory policies, scores (0-5), around $2007^{1}$

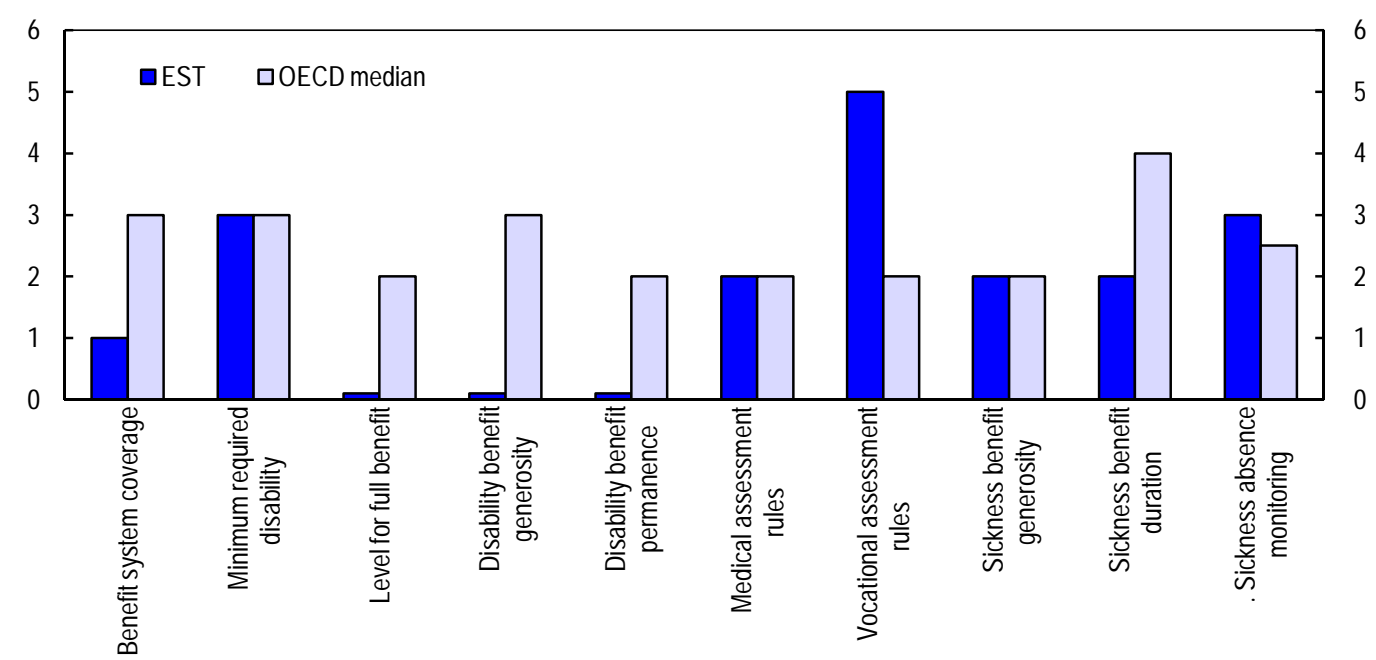

1. 2012 for Estonia.

Source: OECD (2010), Sickness, Disability and Work, Figure 3.1 and Table 3.A2.1A.

Given the already low generosity of compensatory policies, further tightening in the existing system would not be sufficient to improve the efficiency of the system. Reducing the currently high inflow requires more attention to prevention, employer responsibility and rehabilitation. Increasing outflows could be the result of a switch to an activation based model with a strong commitment to regain or even improve incomes from the remaining work capacity. The need for reform has been recognised domestically (Praxis, 2011; NAO, 2010b) and the authorities seem ready to act. The following paragraphs comment in more detail on the main direction of changes. The reorientation of the disability system should be complemented by strengthening of well targeted and activation-oriented short-term income support schemes.

\section{Addressing increasing inflows}

Inflows into the disability and incapacity to work system increased already before the crisis, suggesting a relationship with the bad health status of the Estonian population (OECD, 2010a; Figure 1.1). A role may also have been played by the large inflows of inexperienced and untrained workers into the construction sector during the boom periods before the crisis. Employers do not play an integrated role in preventing work related invalidity beyond the relatively minor co-sharing of sickness related pay during 
the first days. Consequently prevention does not receive the necessary attention. Finally, unhealthy lifestyles are not addressed aggressively enough and the relatively high tobacco and alcohol consumption is taxed only relatively lightly.

The planned introduction of a work accident and occupational sickness insurance is a welcome opportunity to step up prevention activities and establish a stronger responsibility for employers. In-depth monitoring should provide the necessary empirical evidence to design targeted information campaigns and achieve better compliance with respect to protection, prevention and precaution at the workplace and elsewhere, in particular when driving.

\section{Supporting voluntary outflows}

Currently outflows from disability or work-incapacity status are very low. Entitlements are granted for a fixed term from 6 months to 5 years and need to be re-assessed, which is line with international best practices and should encourage outflow from the disability system. As such, they are unlikely to change the conclusion of the previous assessments. In practice, it is very uncommon in Estonia to lose the disability and incapacity to work status (Praxis, 2011): in 2009, only $0.1 \%$ of benefit recipients who underwent assessment lost their entitlement. This is not surprising, because assessment is purely medical and a medically diagnosed handicap, which lasted already for some time is unlikely to go away by itself. On the other side, no support is provided to make most out of the remaining work capacity. There are no targeted rehabilitation services provided and benefit recipients are not offered requalification opportunities. It is therefore not surprising that benefit recipients even when working are not making enough money to escape the risk of poverty. In most other countries activation measures are aiming at generating an income generation capacity, which allows benefit recipients to leave the disability status (OECD, 2010a). Adopting such an approach is necessary to increase voluntary outflows but would require additional competencies to properly design prevention, activation, rehabilitation and re-integration measures.

\section{Implementing reactivation functions}

The current system does not actively support the return to the labour market among those who need help and encouragement. It does not involve any organised activation policies and none of the participating institutions is responsible for promoting employment (NAO, 2010b). Spending is almost entirely restricted to passive benefits. This characteristic is shared by disability and incapacity to work schemes, as well as sickness benefit schemes, whose role in stimulating work-oriented rehabilitation measures at early stages of emerging permanent health problems should be essential. In this respect, Estonia stands in contrast to other countries (Figure 11). For example, several countries spend above $10 \%$ of total spending on disabled on active labour market programmes. Many countries have implemented a rehabilitation-before-benefit principle, and some are now trying to implement a rehabilitation-instead-of-benefit principle (OECD, 2010a). In contrast, in Estonia there is no training support, and there are no incentives for those with partial loss of work capacity to participate in re-qualification measures. Rehabilitation takes place very late, when health problems are already aggravated, and it is not directed at facilitating return to work. The effectiveness of existing support that has some activation dimension should also be monitored, for example only $15 \%$ of persons who received the special benefit for purchasing technical aid to facilitate their participation in social life (and presumably professional life) in fact purchase such goods or services (NAO, 2010b). Employers are weakly involved in activation measures and no motivation is provided for employers to re-employ people with a health problem or partial incapacity. 
Figure 11. The disability system provides few integration measures

Integration policy dimension: country scores (0-5), around $2007^{1}$

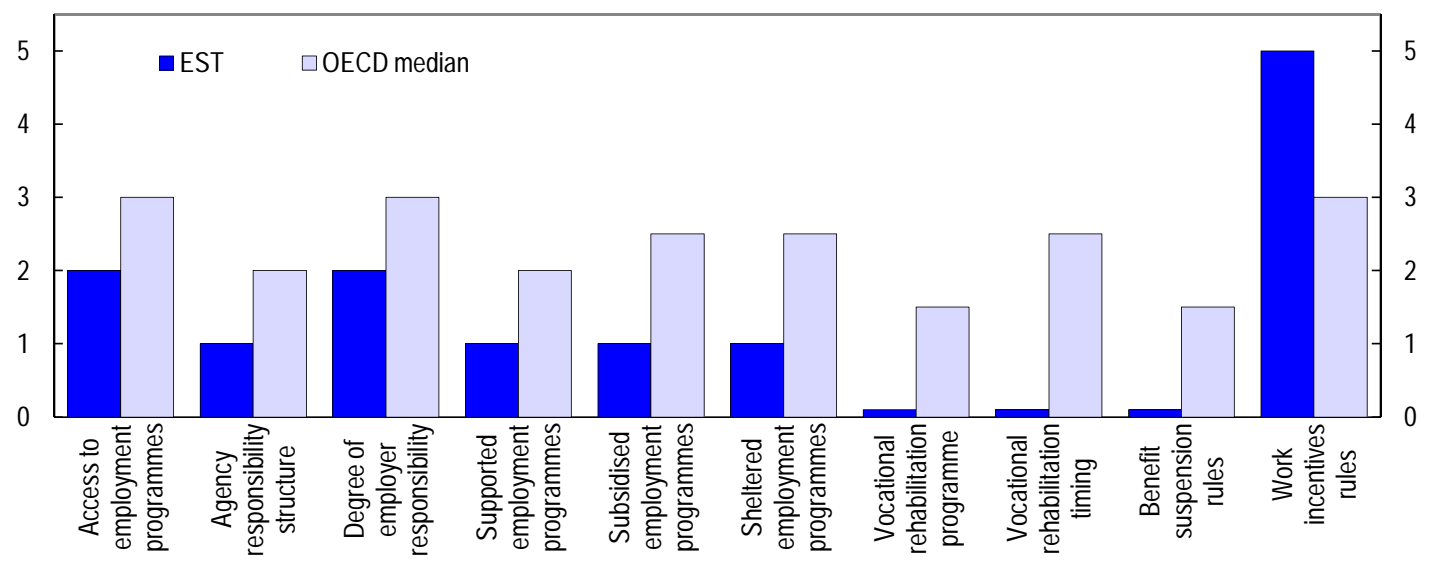

1. 2012 for Estonia.

Source: OECD (2010), Sickness, Disability and Work, Table 3.A2.1B; and Estonian authorities.

An overhaul of the disability system would need to focus on providing rehabilitation, training and specialised support facilitating return to work from the early stage of health problems. Much closer cooperation between institutions operating the system and the unemployment insurance fund would be needed to achieve such a change. Opportunities should be given to learn a new profession in line with the new health status to prepare for re-entry into work, and the take-up should be encouraged, starting with those on long-lasting sickness leaves, who face a high risk of losing a high share of income generating capacity. Individual return to work action plans should be routinely prepared. Participation in activation programmes should be part of a disability benefit catalog, especially among those with lower incapacity for work. In other words, benefits should be rebalanced between cash and in-kind forms. The role for employers in reactivating workers and creating more suitable working conditions for those who return to the market also needs to be foreseen and actively supported. For example, in some countries, employers are obliged to develop, follow and update reintegration plans. It must be financially profitable for employers to retain workers with health problems or to reintegrate them efficiently into the same or another job.

\section{Reducing institutional complexity and case-managing clients}

The current disability system is fragmented among different institutions, and Estonia also stands out by international comparison in this respect. Many agencies are involved in benefit and service provision. The disability allowance and the incapacity to work schemes overlap (NAO, 2010b). The permanent incapacity to work scheme administered by social insurance fund also interacts with sickness scheme administered by health insurance fund. There is no effective coordination between those programmes, regarding the challenge of keeping benefit recipients close to the labour market. While people are being shifted across different schemes, it is more difficult to case-manage each client, providing tailor-cut support at the right moment. In addition, currently the types of support provided by local authorities to the disabled vary greatly, depending on their financial capacities. No national standards, financing or capacity building is available (NAO, 2010b).

Improving the system would be best achieved through the full integration of permanent incapacity to work pensions, disability allowances and sickness benefits into one system administered by one institution oriented to activation (OECD, 2010a; NAO, 2010b). This would ease problems of effective control, policy planning and implementation, as well as harmonization of assessment methodologies. In particular, all clients should be case-managed through the system, with their profile reviewed early and then making 
every effort to support their earnings capacity. This would also help to improve linkages with other parts of the social system, which would play an important role in preventing permanent disability: i) a more employment-oriented occupational health service that encourages doctors to monitor sickness absences and engage employers to avoid the aggravation of health problems through workplace conditions; ii) an unemployment insurance fund that provides activation measures; and iii) municipalities that provide social benefits and additional social services.

Occupational disease and work accident insurance, which is still absent in Estonia, should also become part of the reformed disability system, with differentiated risk premium leading to stronger prevention efforts among employers and greater incentives to bring people back to work.

\section{Targeting transfers without negative work incentives}

One positive outcome of the disability system in Estonia is a relatively high rate of employment among the system recipients, especially prior to the crisis (Figure 12). This is partly explained by the fact that the size of the disability benefit and incapacity pension does not depend on working income. Secondly, the actual size of the benefit is small, establishing the need to mobilise the remaining earnings capacity. Both imply strong work incentives. In making the best use of limited financial resources, there might be a case for providing invalidity-related benefits to some extent in-kind in order to optimise the benefits from the remaining work and earnings capacity.

Figure 12. Employment rate among the disabled is high

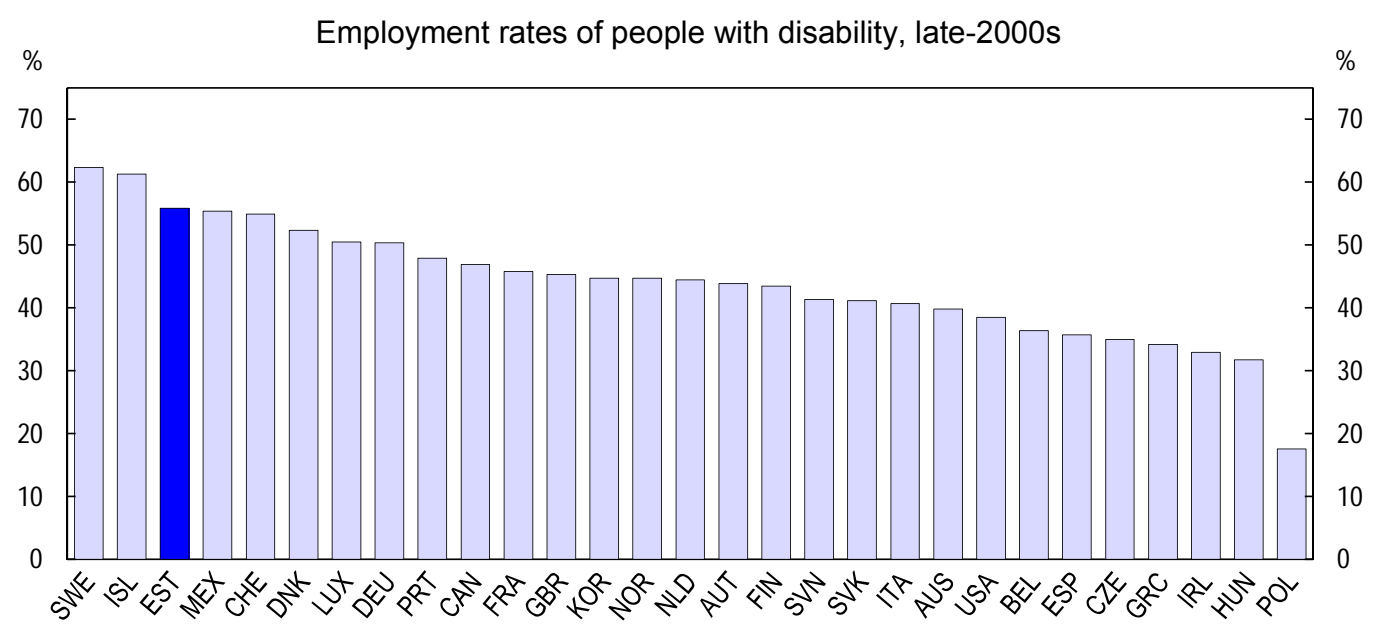

Source: OECD (2010), Sickness, Disability and Work, Figure 2.1.

\section{Providing more effective support to the unemployed}

The high volatility of the economy and overall labour market flexibility mean rapid unemployment increases at times of a general slowdown or sectoral employment shifts. It is therefore important that the unemployment protection system provides adequate short-term income support, mitigating poverty risk among those losing a job and facilitating active job search. At the same time the system should maintain strong work incentives and prevent transition to inactivity, including through other parts of the social protection schemes, notably disability. The current labour market outcomes include a large share of long-term unemployed, who should be more effectively activated. These multiple policy objectives are currently met only partially by the existing two-tier system of unemployment protection complemented by the social assistance scheme, suggesting scope for changes within the system. Challenges include: 
- The poverty prevention effect is weak, as coverage of the unemployment insurance benefit and the size of the unemployment assistance benefit are low (Figure 2.13). Unemployment assistance recipients are therefore frequently recipients of subsistence benefit (30\% in 2009 and $10 \%$ in 2011), as it is possible to combine benefits.

- Work incentives under unemployment protection schemes are generally strong, but many of those losing work and unemployment entitlements make transitions to the disability system or become recipients of subsistence benefits, where they are not systematically activated.

- The system withstood the recent crisis financially, but required a substantial increase in contribution rates to the Unemployment Insurance Fund (UIF), directly increasing the labour tax wedge. The system is again in surplus.

Figure 13. Unemployment benefits coverage is low
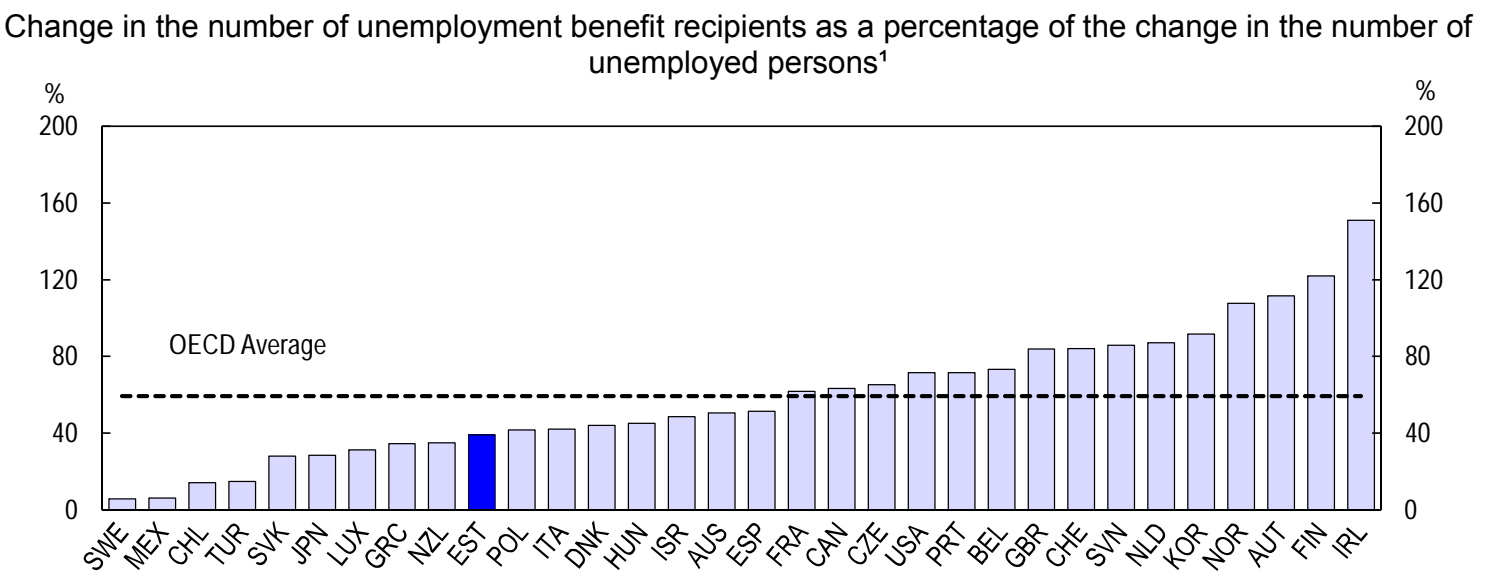

1. During first year since the onset of the crisis. Total unemployment benefits including extended benefits and unemployment assistance.

Source: OECD (2011), Employment Outlook, Figure 1.17B.

\section{Fine-tuning unemployment insurance}

Effective coverage of the unemployment insurance benefit is low. Prior to the crisis less than a quarter of registered unemployed received the benefit. This share increased during the initial phase of the crisis, as almost half of the newly registered had a right to the benefit. However it is now very low again, including by international standards (Figure 14). Most registered unemployed are not eligible for the benefit because they have exhausted their rights. Others did not work as contributing employees, or they are considered as voluntarily unemployed. The requirement of 12 month contribution during last 36 months is stricter than in most OECD countries (Figure 15A). Loosening the eligibility conditions could therefore be considered to provide more income support in the initial phase of the downturn (OECD, 2010b). Indeed, the amendment to cover those unemployed whose employment contract was terminated by mutual agreement was to be implemented in 2009, but was postponed until 2013 as part of the crisis response. It is now likely to be abolished. Resistance to relaxing eligibility criteria is linked to the large fiscal costs due to the relatively high level of unemployment insurance benefits and there are more efficient ways of mitigating the social costs of labour market shocks as discussed below. 
Figure 14. Half of registered unemployed do not receive any benefits

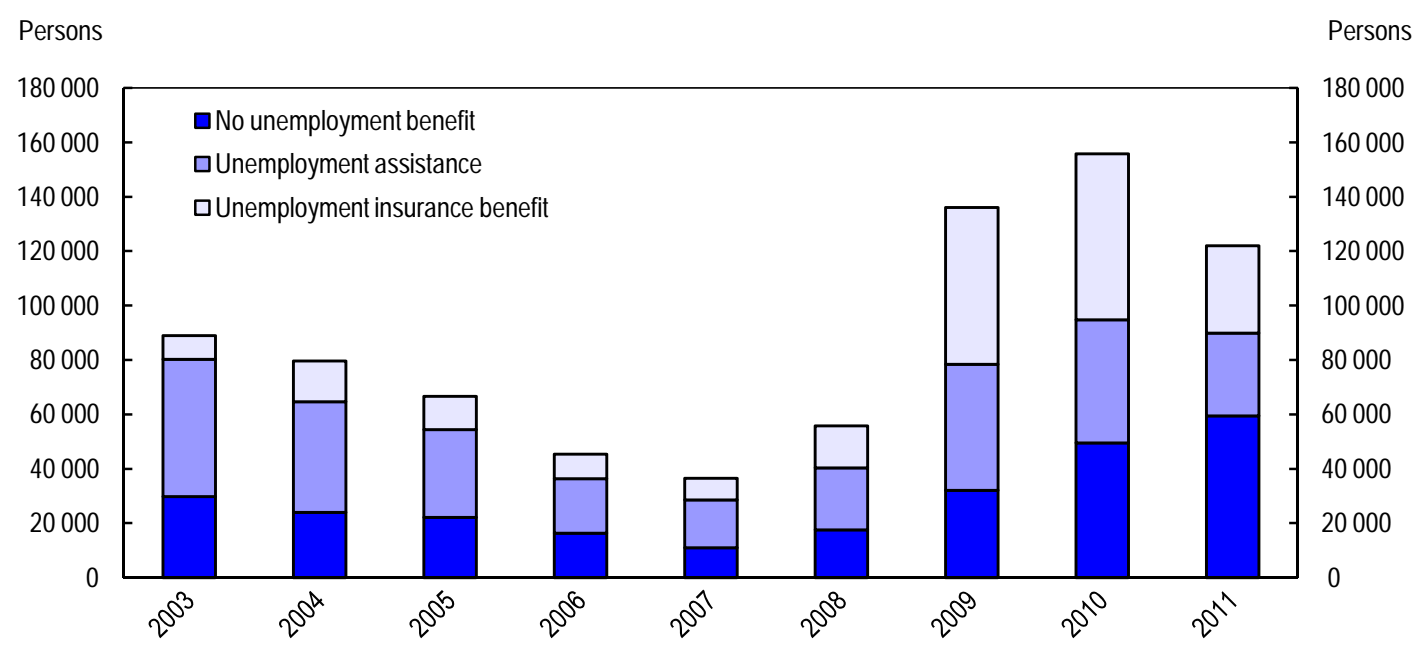

Source: Estonian Unemployment Insurance Fund.

The length of the unemployment insurance benefit is broadly appropriate and similar to the OECD median level. It could be reduced in upturns, when the general unemployment rate is low. This would provide some additional budgetary space to lessen eligibility criteria, reduce contribution rates or to reduce net public debt. More importantly, this would further reduce job search disincentives, which are more important in upturns (Landais et al., 2010; Lauringson, 2011) and hence reduce the average length of unemployment spells. Changing the duration of unemployment benefits would have a stabilising role, with public outlays falling more strongly in the upturn and increasing the effectively available labour force during times of shortages. By reducing the reservation wage, a shortened duration would reduce wage pressures in the boom phase of the cycle. Current benefit duration should continue to apply in downturns when finding employment is much more difficult and competition among job seekers is the highest, so the disincentive impact is less important. But a duration increase in the downturn does not seem needed if income support after insurance benefit exhaustion were stepped up as discussed below.

The length of the unemployment insurance benefit period is effectively increased for recipients of severance payments, as the unemployment insurance benefit period begins only after months during which the severance is paid. This changed since mid-2009 to avoid accumulation of payments in the early phase of the unemployment spell: before then the unemployed could receive both severance and unemployment insurance at the same time. However, the maximum period of severance pay was cut from four to three months (with only one month being covered by the employer) in the case of workers with 10 years tenure, and is lower for the large majority of workers. It remains important that, especially in this initial period, job search requirements not to be relaxed.

The unemployment insurance benefit system offers strong incentives for job search in terms of job search requirements (Figure 15). This is important because theoretical and empirical studies confirm that job search requirements and associated sanctions influence both search intensity and the reservation wage, and hence unemployment outcomes (Fredriksson and Holmlund, 2006; Lalive et al., 2005; Hofman, 2009). If an unemployed person refuses a suitable employment offer without good reason, the payment of the unemployment insurance can be terminated immediately. Also, the unemployed person must remain available and actively looking for a job during the ALMP participation, which is quite strict in international comparison (Venn, 2012). Job search has to be proven monthly. However, the definition of suitable work could be tightened. In particular, requirements of geographical mobility are less strict than in most OECD countries: an unemployed person can refuse a job if travel costs are higher than $15 \%$ of the monthly salary, or daily commuting time exceeds two hours. Secondly, the definition of suitable work during the first 20 weeks includes only jobs that correspond to the beneficiary's professional qualification, education level 
and previous professional experience. The unemployed person can reject an offer due to family obligations or if it entails a salary that is more than $40 \%$ lower than the past average. These conditions are relatively liberal by OECD standards (Venn, 2012). It is only after 20 weeks that an unemployed person has to accept any job that is available, but even then the salary has to be higher than the unemployment benefit, which constitutes a disincentive for low-pay jobs, which can be important for activation.

Figure 15. Employment record requirements are relatively strict compared to job search obligations

\section{A. Strictness of entitlement conditions}

Scored from 1 (least strict) to 5 (most strict), 2011

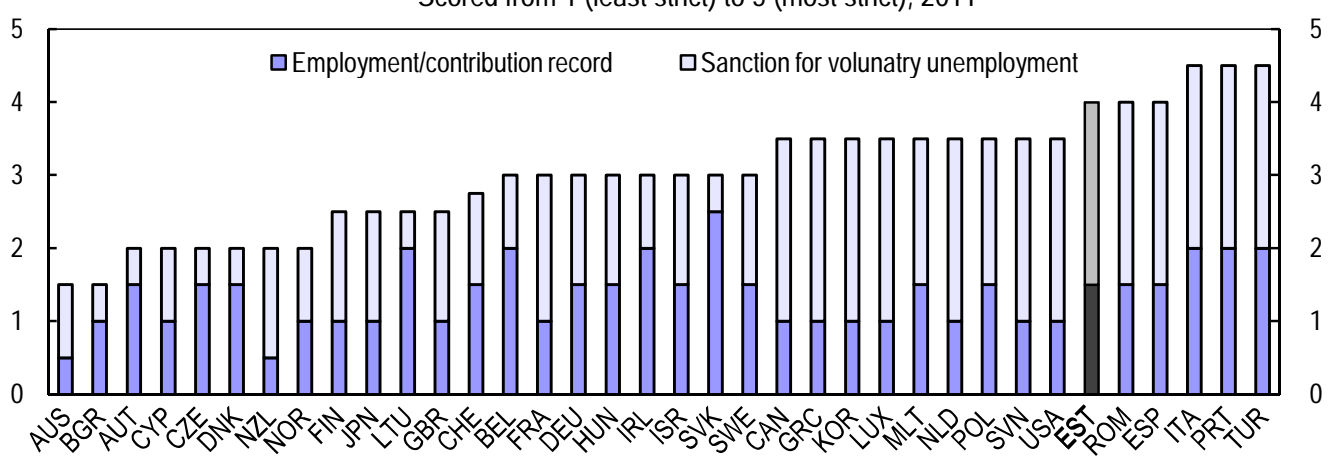

B. Strictness of job-search and availability requirements

Scored from 1 (least strict) to 5 (most strict), 2011

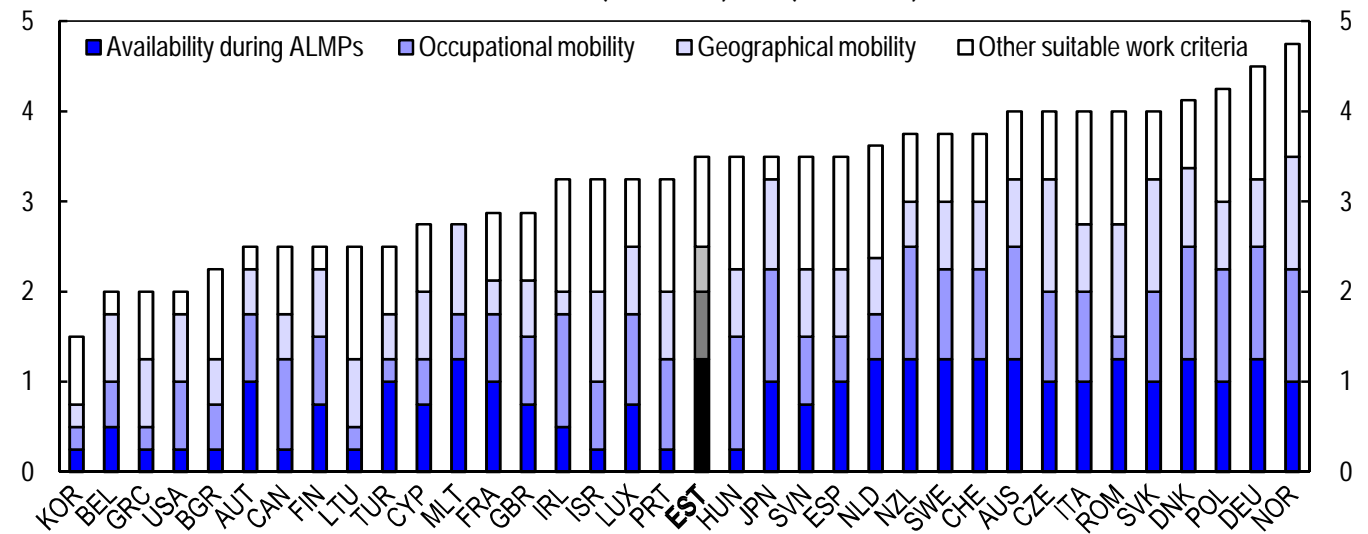

Source: D. Venn (2012), Eligibility Criteria for Unemployment Benefits, Figures 2 and 3.

Replacement rates are in line with international benchmarks and indeed more generous relative to other social programmes in Estonia. Making them even more generous, as initially planned in 2009, would have been costly and could have damaged job search incentives (OECD, 2009; Lauringson, 2010). Therefore, decisions to first suspend the replacement rate increase until 2013 and then to abolish it seems justified. Other changes to benefit calculation could be considered. The benefit is capped at a relatively high level of $150 \%$ of the country's average wage from the previous year, which is well above international averages (OECD, 2012a) and this ceiling could be lowered. The replacement rate could also be reduced progressively, while the minimum benefit should remain at around half of the minimum wage. It should also be added that neither private insurance, nor individual accounts are likely to provide adequate protection for the low-skilled, who face high risks of losing jobs and low capacity to accumulate sufficient resources (Praxis, 2011). 


\section{Increasing the role of unemployment assistance}

A large share of the unemployed do not qualify for the unemployment insurance benefit, nor for unemployment assistance. This left half of the unemployed without any income support from local UIF offices in 2011. While it provides strong job search incentives, it also leads to flows into other schemes that do not provide activation services. There is also the risk that these clients do not receive the same attention as benefit recipients. Entry conditionality and duration of unemployment assistance could therefore be relaxed to allow for wider coverage and enhance its role as the main employment-promoting income support scheme. The expansion of unemployment assistance would be particularly useful in combination with reforming disability system, which currently often provides a benefit of last resort to those who lost other entitlements. Fiscal costs would be lower than expanding the unemployment insurance benefit, and can be covered from general taxation rather than more distortive labour taxation.

The size of the benefit should be also stepped up to the level that minimises the risk of poverty and allows for covering expenses in looking for a job. Higher benefits would also raise the cost of reneging on job search and training requirements. They would also minimise the need to combine both unemployment assistance and subsistence benefit, which was happening for 30\% of recipients in 2009. It is therefore welcome that the increase in the size of benefit that was originally planned for 2009 , but suspended in the crisis, will finally happen in 2013. Doubling the size of the benefit would have an important impact on poverty. The impact on incentives to work - present even at the times of downturn (Lauringson, 2011) should be modest as current replacement rates are very low (Figure 16) and, even after the increase, unemployment assistance would be only half of the minimum wage and $15 \%$ of the average wage. At the same time this benefit could be income-tested replacing the existing simple cut-off rule that own income cannot exceed the size of the benefit, and the test could be household-based, as is the case in most countries that provide unemployment assistance (Table 2). This would allow an increasing poverty reduction impact at limited fiscal cost. However, benefits should be reduced only gradually while household income is increasing, to avoid disincentives for spouse employment. Tests on assets could be also considered, as these are likely to reduce distortions, even though they can be more difficult to administer (OECD, 2011b).

Figure 16. Unemployment assistance benefit is very low

Maximum benefit as a share of average wage ${ }^{1}, 2010$

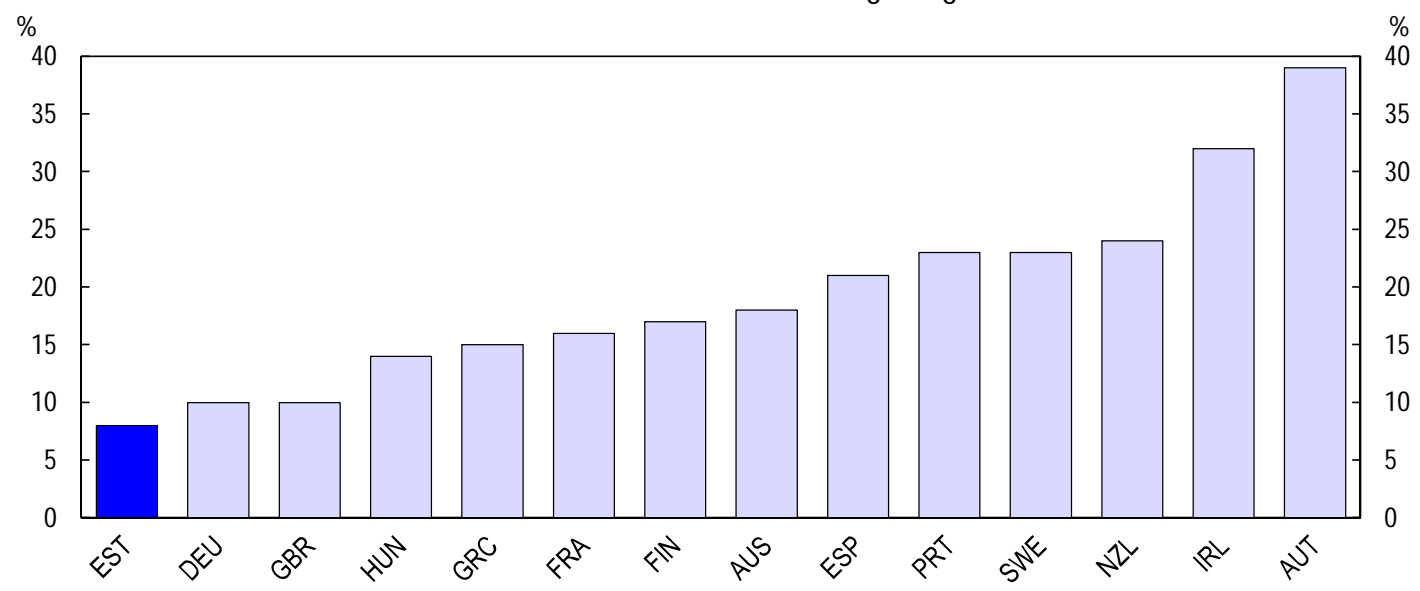

1. For a 40-year-old single worker without children, with a 22-year employment record. For Germany, as of 1st January 2005, unemployment assistance and social assistance for persons who are able to work were combined into one benefit, the basic jobseekers allowance (unemployment benefit II). Available for persons who are able to work and whose income is not sufficient to secure their own and their family's livelihood.

Source: OECD Benefits and Wages Indicators (www.oecd.org/els/social/workincentives). 
Table 2. Means-testing of unemployment assistance in OECD countries

\begin{tabular}{l|l}
\hline $\begin{array}{l}\text { No means-testing } \\
\text { Income-testing, individual }\end{array}$ & $\begin{array}{l}\text { Spain } \\
\text { Estonia, Hungary, Sweden }\end{array}$ \\
$\begin{array}{l}\text { Income-testing, family } \\
\text { Australia, Austria, Finland, France, Germany, Greece, } \\
\text { Ireland, New Zealand, Portugal, United Kingdom } \\
\text { Asset-testing, family }\end{array}$ & Australia, Austria, Germany, United Kingdom \\
\hline
\end{tabular}

Source: www.oecd.org/els/social/workincentives.

Sanctions for non-compliance with job search requirements should be increased for recipients of unemployment assistance. According to the Labour Market Services and Benefits Act, all registered unemployed have the same job-search and activation requirements. However, sanctions for noncompliance are somewhat lower for recipients of unemployment assistance compared with recipients of unemployment insurance benefits. While missing an appointment at the UIF office or rejecting a job offer without a good reason leads to the immediate loss of the unemployment insurance benefit, these lead to only short-term suspension of unemployment assistance, and loss only in case of repeated non-compliance. These less restrictive sanctions might reflect the mutual obligation principle, in which the recipient of much higher unemployment insurance benefits can be expected to do more to return to employment. On the other hand, recipients of unemployment assistance face a higher risk of longer term unemployment, so similarly strict sanctions should therefore be extended to them and activation policies stepped up.

\section{Activating recipients of subsistence benefits}

Some $1 \%$ of the population receive subsistence benefit, and almost three quarters of recipient households have members registered as unemployed, including long-term unemployed for whom subsistence benefit can be the sole source of income. While the number of recipients was falling prior to the crisis, the number of new claims almost tripled between 2008 and 2010, reflecting increasing unemployment. At about one quarter of the median household income, the average amount of the benefit is among the lowest in the OECD (Figure 2.17), and well below the standard relative poverty line. This results in a very low level of spending on social assistance in Estonia (only $0.05 \%$ of GDP prior to the crisis and roughly $0.1 \%$ of GDP in 2010 , compared to an average of around $1 \%$ of GDP spending in both EU and OECD countries). The poverty reduction role of the subsistence benefit is therefore limited, even though the benefit is well targeted, and - not surprisingly - Estonia has one of the highest share of beneficiaries that remain in poverty. Poverty and liquidity constraints among beneficiaries might constrain job search (OECD, 2011b), so an increase in subsistence benefits could help the most cash-poor individuals to engage more successfully with the labour market, especially, if coupled with stronger activation policies. Asset testing could be considered to reduce the risk of unjustified claims. 
Figure 17. Subsistence benefits are low in international comparison

Net income value as a percentage of median household incomes, lone parent with 2 children, 2010

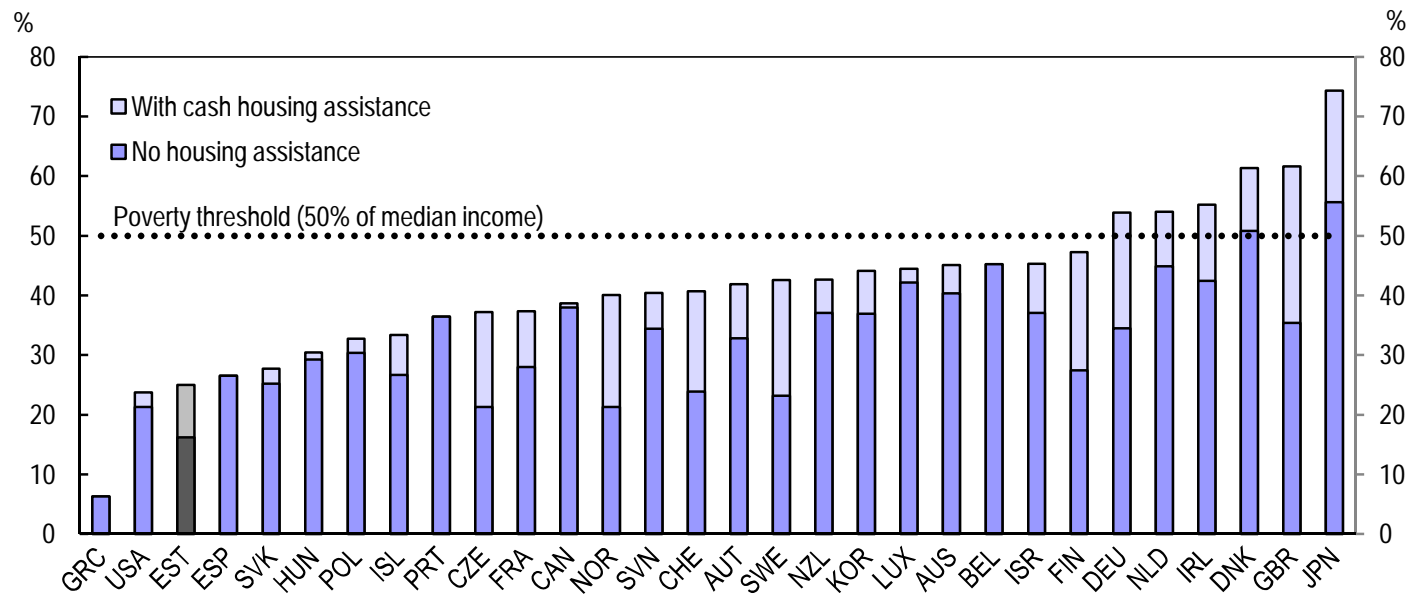

Note: Median net household incomes adjusted for household size are for a year around 2008 expressed in 2010 prices and are before housing costs (or other forms of "committed" expenditure). Results account for all relevant cash benefits (social assistance, family benefits, housing-related cash support as indicated). Calculations for families with children assume two children aged 4 and 6 and neither childcare benefits nor childcare costs are considered. The "cash housing assistance" indicates the range of benefit levels in countries where they depend on actual housing expenditure.

Source: OECD Benefits and Wages Indicators (www.oecd.org/els/social/workincentives).

The lack of binding job-search requirements and assistance is an important problem of this scheme. Municipalities can, according to the Social Welfare Act, refuse to grant a benefit to a person of working age who is neither working or studying and has declined repeatedly to take suitable job offers, or to participate in education or rehabilitation programmes offered by the municipality. However, in practice it is very rare for municipalities to sanction recipients with the loss of benefit. Incentives to do so are even lower because the benefit is administered locally but financed from the central budget. The practice in most of the OECD countries is to make social assistance and household cash transfers strictly conditional on participation in programmes proposed by the local UIF office or municipality (Table 3), as recommended by the Reassessed OECD Jobs Strategy (OECD, 2006). Such strict conditionality should be considered in Estonia.

Table 3. Job-search requirements in social assistance schemes

\begin{tabular}{l|l}
\hline \multicolumn{2}{l}{ Job search/registration with PES/integration activities/Work requirement } \\
\hline Required & $\begin{array}{l}\text { Australia, Austria, Canada, Czech Republic, Denmark, France, Germany, Hungary, Ireland, } \\
\text { Israel, Japan, Korea, Luxembourg, Netherlands, New Zealand, Norway, Poland, Portugal, } \\
\text { Slovenia, Spain, Sweden, Switzerland, UK, US }\end{array}$ \\
Discretionary & $\begin{array}{l}\text { Estonia, Finland } \\
\text { None }\end{array}$ \\
\hline
\end{tabular}

Source: www.oecd.org/els/social/workincentives.

Increasing the activation function of the subsistence benefit would require better coordination between municipalities and the Unemployment Insurance Fund. Such cooperation has been promoted recently through pilot projects bringing together staff from the local UIF offices and social workers, and targeted a selected group of long-term unemployed. The focus has been on practical job search and work skills, training, counselling, boosting motivation and seeking direct contact with employers. In 2011 one municipality in every county participated and, given the success of the projects, participation has been increased to 3 municipalities in every region. It is important that lessons from these pilot projects are mainstreamed into normal work patterns. One practical problem for day-to-day cooperation that needs to 
be overcome is the complexity of public procurement requirements, triggered when the local UIF office wants to engage municipalities in activation policies.

In considering an optimal allocation of the tasks of activating and supporting the unemployed with multiple obstacles for employment, the limited resources of municipalities need to be recognised. This suggests shifting responsibility increasingly towards the UIF local offices. This should be first supported by compulsory UIF registration for subsistence benefit recipients so that those with some capacity to work should all become clients of the unemployment insurance fund. This would reduce the burden of work on social workers and would allow them to tackle the deeper determinants of inactivity, including social exclusion and behavioural pathologies. In a more radical reform scenario, the minimum income guarantee programme could be provided by more accessible but a means-tested unemployment assistance allowance with strict job search conditionality, allowing transferring all able to work out of the subsistence benefit programme. Such a model of fully integrated social assistance and labour market polices has been successful in countries such as Australia and New Zealand (Box 5), with important elements implemented in Germany with the introduction of the basic jobseekers allowance (OECD, 2010c).

\section{Box 5. Unemployment assistance in Australia and New Zealand}

Unlike most OECD countries, Australia and New Zealand provide a flat (non-earnings related) means-tested allowance to meet social risks, which may be paid for an unlimited period and is not subject to employment record conditions, but which has strong job search obligations. No unemployment insurance benefit scheme linking benefits with past wages is available. There are no other comprehensive social assistance benefits. The maximum amount of benefit corresponds to 18 and $24 \%$ of the average wage respectively in each country. To prevent disincentive against work, the benefit is withdrawn only gradually, as the work income increases. In Australia, there is a $50 \%$ benefits withdrawal rate up to the first income threshold, and $60 \%$ up to the second threshold. In New Zealand, the benefit withdrawal rate is at $70 \%$ above a single threshold.

Source: OECD (2010d).

\section{Re-adjusting different social benefit schemes addressed to the working-age population}

Increasing the effectiveness of the social protection system would require adjustment across different social spending schemes, as discussed above. Table 4 provides a summary overview of what would be necessary to move towards a system of more activation-oriented and more targeted social benefits.

Table 4. Reforming income-support: the possible road map

\begin{tabular}{lllll}
\hline & \multicolumn{1}{c}{$\begin{array}{c}\text { Incapacity to } \\
\text { work benefit }\end{array}$} & $\begin{array}{c}\text { Unemployment } \\
\text { Insurance Benefit }\end{array}$ & $\begin{array}{c}\text { Unemployment } \\
\text { Assistance }\end{array}$ & $\begin{array}{c}\text { Subsistence } \\
\text { Benefit }\end{array}$ \\
\hline $\begin{array}{l}\text { Entry eligibility } \\
\text { requirements }\end{array}$ & Tighten & No change & Relax & Asset testing \\
\hline Length of benefit & Tighten & Shorten in booms & Lengthen & No changes \\
\hline $\begin{array}{l}\text { Job search } \\
\text { requirements }\end{array}$ & Introduce & Tighten & Tighten & Make compulsory \\
\hline $\begin{array}{l}\text { Activation } \\
\text { policies }\end{array}$ & Introduce & Strengthen & Strengthen & Make compulsory \\
\hline $\begin{array}{l}\text { Average size of } \\
\text { benefit }\end{array}$ & No changes & No changes & Increase & Increase \\
\hline $\begin{array}{l}\text { Determining the } \\
\text { size of benefit }\end{array}$ & No changes & Flatten & Partial withdrawal & No changes \\
\hline
\end{tabular}

Source: OECD analysis. 


\section{Refocusing family support policies}

Estonia offers the most generous maternal and parental leaves in the OECD (Figure 18), which explains why family policies account for almost half of all social transfers in Estonia, apart from old-age pensions. This generosity is in striking contrast to the rest of the social protection system, including on other family policies such as income support to poorer families with children and spending on formal childcare provision, where Estonia spends relatively little. Although the duration of maternity leave in Estonia is around the OECD average of 19 weeks, the 100\% replacement rate throughout the leave is substantially more generous than in most other countries. When the maternity leave is completed, women can take a parental leave which is paid for 62 weeks, again with a $100 \%$ replacement rate, as well as subsequent prolonged periods of leave to care for young children. The total length of leave can go up to 136 weeks, among the highest in the OECD in terms of duration and average replacement rates. This is despite the fact that cross-country studies have not produced convincing evidence regarding the influence of paid and unpaid leave entitlements on fertility. While the impact of duration and generosity can have a different sign dependent on the study, the overall effects of fertility are generally considered as being small, even if they can affect the timing of births (Adsera, 2004). This is because temporary financial transfers can cover only a small part of the life-cycle opportunity cost of having children (Thévenon and Gauthier, 2011).

Figure 18. Maternity and paternity leaves are exceptionally generous in Estonia

Full-rate equivalent length ${ }^{1}$ of maternity and parental leaves for the average worker, weeks, 2008

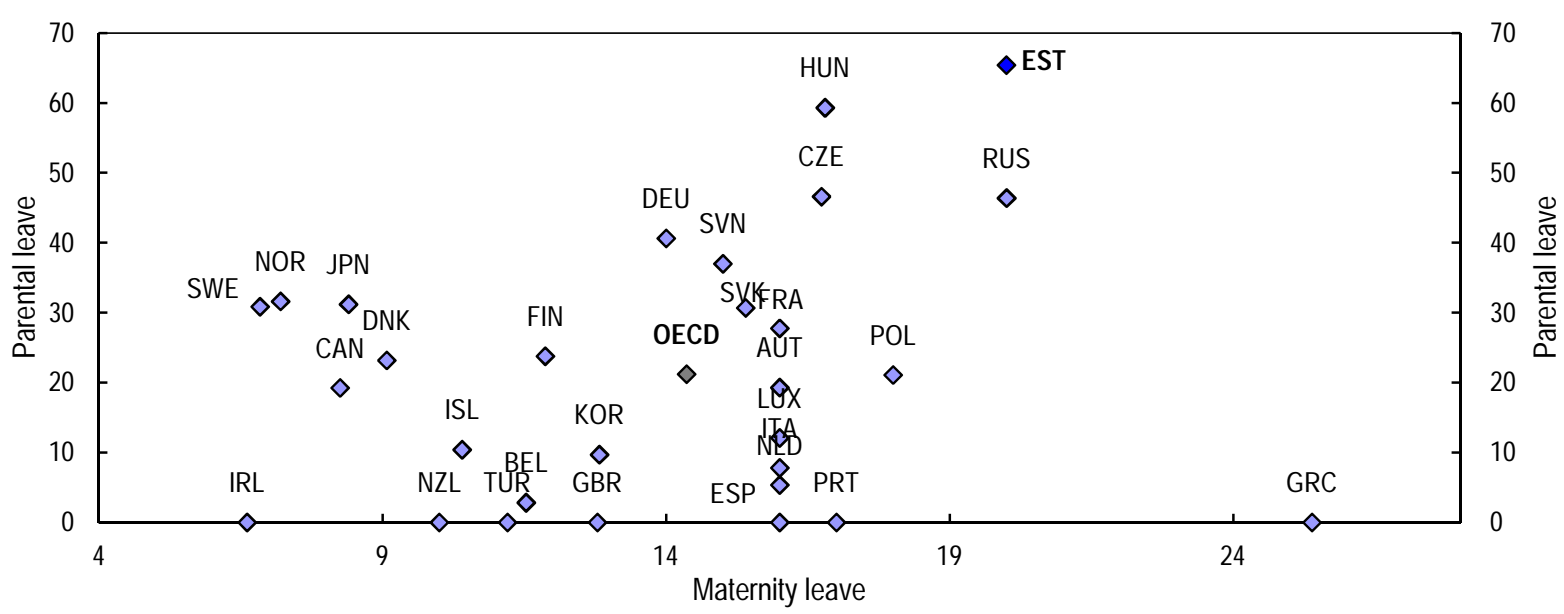

1. Full-rate equivalent length is the product of the total length of leave and the average replacement rate.

Source: OECD (2011), Doing Better for Families, Figure 4.1.

Expenditures on maternity and paternity leaves might therefore not be the most efficient for meeting the most important goals of family policies: increasing fertility rates and reducing child poverty. According to the international evidence these are best supported by policies facilitating the employment of mothers (OECD, 2011e). While Estonia succeeded in raising the fertility rate above the European Union average and reports relatively high female employment rates (Figure 19), several countries with less generous entitlements, notably the Nordic neighbours, have achieved a much better outcome on both the fertility rate and female employment. At the same time, child poverty in Estonia remains high by international standards. Absolute poverty among children increased sharply in the crisis and is more than twice as high as the total population average. It is particularly high for sole parent families with children. But in contrast to generous parental and maternity leaves, flat-rate family allowances are modest, especially at EUR 19 monthly for the first and second child, and also for a single parent, and do not seem to contribute 
sufficiently to the reduction of child poverty. This suggests the need for a readjustment of family spending from maternal and paternity leave entitlements towards targeted child allowances and childcare provision.

Figure 19. There is still much scope to increase both fertility and female employment rates

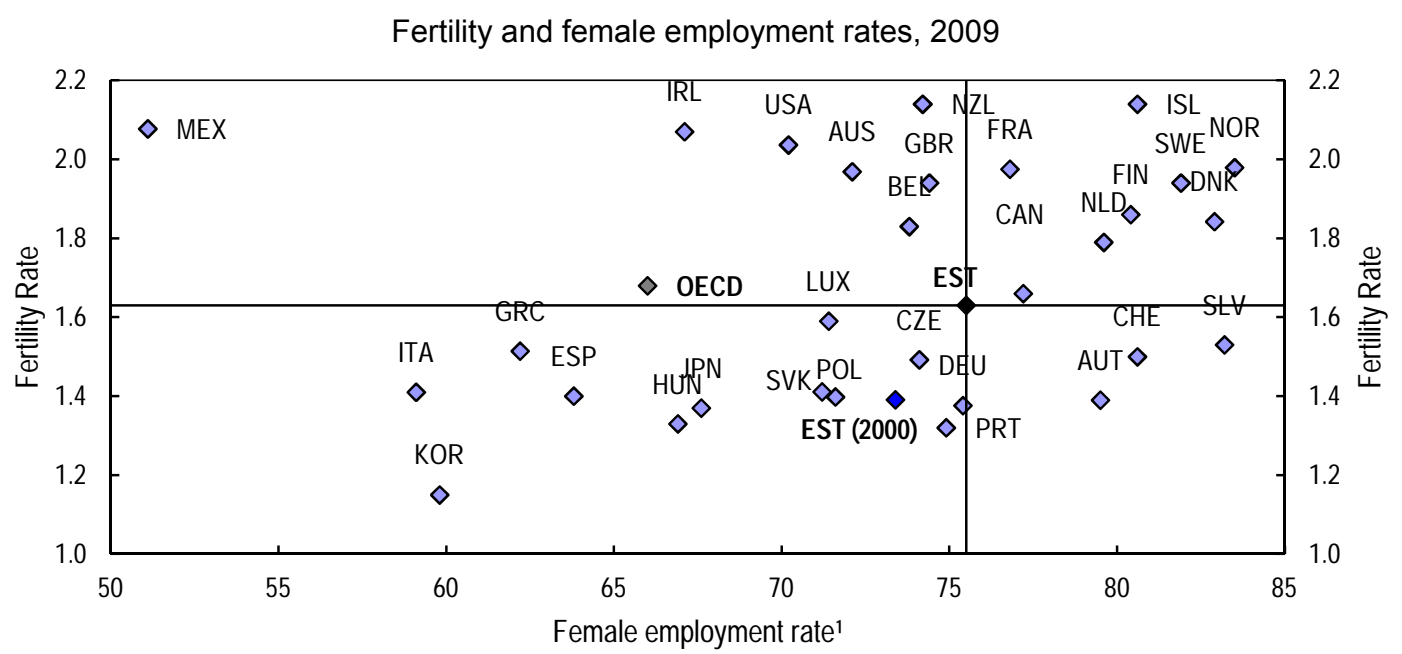

1. Female population aged 25 to 54 .

Source: OECD (2011), Doing Better for Families, Figure 3.8; and Statistics Estonia.

Estonia spends relatively little on public childcare provision (Figure 20), although the availability of childcare institutions is one of the main factors explaining cross-national differences in fertility between countries. Cross-country and national studies conclude that the overall development of childcare across the OECD since the early 2000s has significantly increased second and higher order births for women (Hilgeman and Butts, 2009). Although the effect of public spending on childcare services is less certain, it seems that reductions in the parental fee paid for affordable good-quality childcare can have a positive effect on fertility rates (Rindfuss et al., 2010). Part-time employment opportunities have a positive effect on fertility rates, particularly among women with a higher level of educational attainment, although the effects are likely to be country-specific (d'Addio and Mira d'Ercole, 2005). At the same time, spouse employment is an important family insurance policy against macroeconomic risks (Ahrend et al., 2011). Access to affordable formal childcare allows participation in paid work, reducing poverty risks. Although pre-primary education is not compulsory in Estonia, most working parents have access to day-care for their children, organised as baby groups or nursery schools up to age 3 and pre-primary institutions for children aged 4 to 6 , which are usually open for 10-12 hours a day to facilitate work. The fee paid by the parents is decided by local municipalities and cannot exceed $20 \%$ of the minimum wage, although the institution can decide upon the amount paid for catering costs. Fees do not seem to be a barrier, with the usage rate by low-income parents actually higher than average, unlike in other OECD countries. Nevertheless, it seems that the number of available places has not fully kept pace with the increasing number of children between 18 and 36 months old, indicating that not all of them can be guaranteed a place, despite high demand. The need to expand childcare should therefore be examined. 
Figure 20. Low spending on childcare might contribute to low enrolment rates

A. Public expenditure on childcare including pre-primary education, \% of GDP, 2007

$\%$

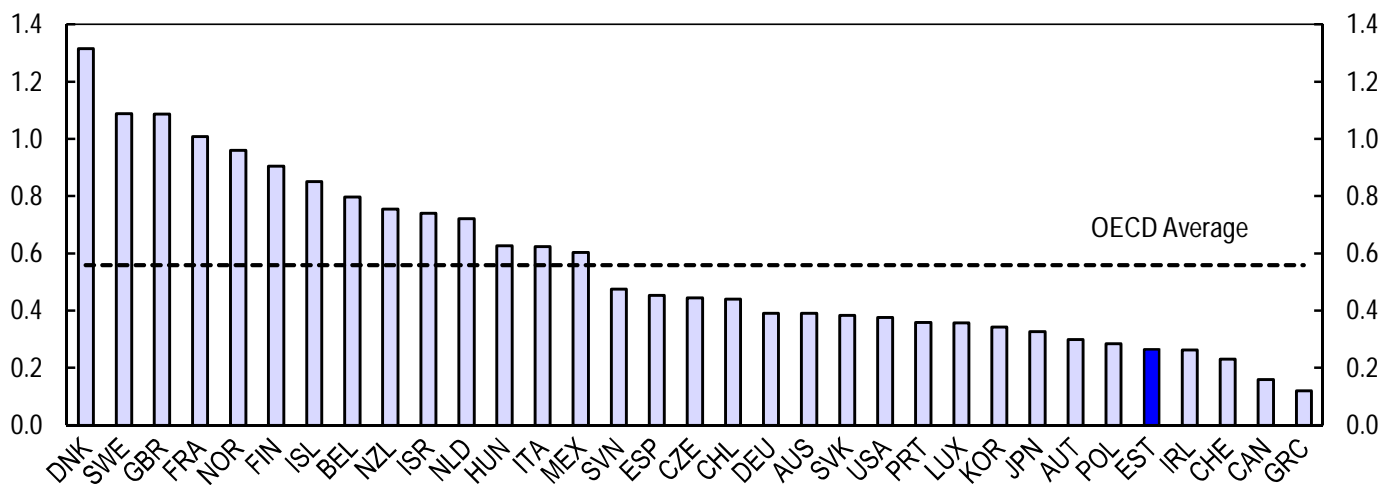

B. Childcare enrolment rates for $<3$ year olds (childcare or in-school), 20081

$\%$

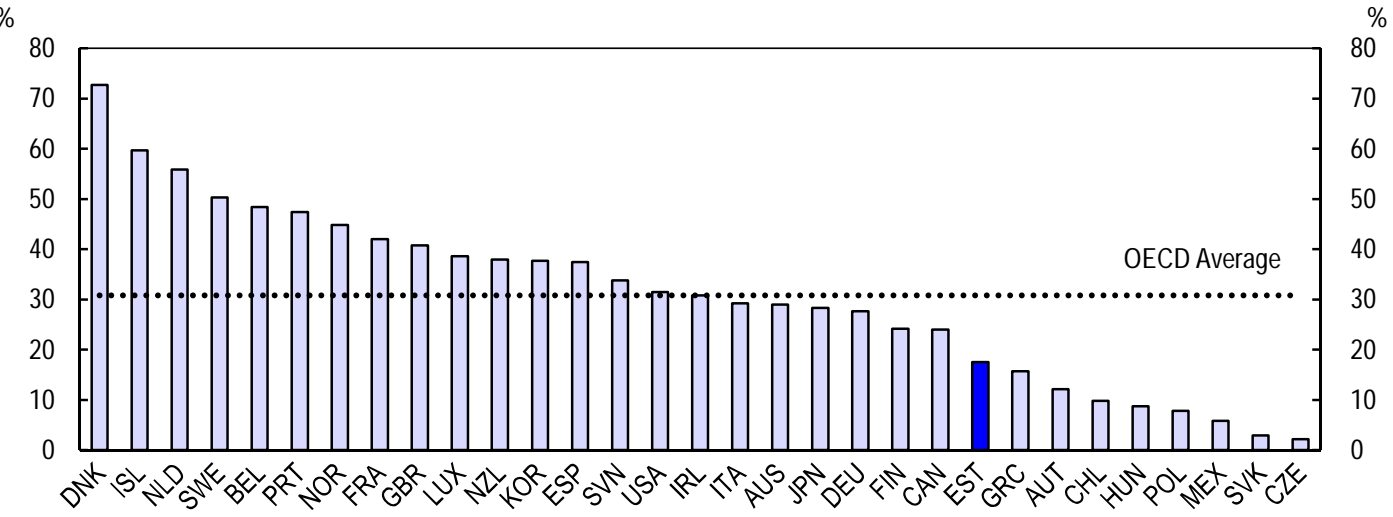

1. 2005 for the United States; 2006 for Canada; 2009 for Mexico.

Source: OECD Family database; OECD (2011); Doing Better for Families, Figure 4.5.

The government has recently prepared changes to the pension system that would increase replacement rates in case of child-bearing career breaks. However, a planned government-financed pension contribution for child-caring periods up to three-years is a costly and inefficient way of promoting fertility or reducing old-age poverty. First, there is no clear international evidence on the relation between pension systems and fertility. Second, a better way to address old-age poverty among females is to improve childcare and promote more fair child burden sharing among parents, helping mothers to reconcile work and family life and contribute to the pension system.

\section{Improving access to quality health care}

Access to good quality healthcare services contributes directly to the better health status and ability to participate actively in social and economic life. It can have an important role in mitigating the impact of income volatility on individual well-being. Unfortunately, health outcomes in Estonia are generally among the weakest in the OECD (Figure 21). Despite strong recent gains, life expectancy in Estonia at 75 years is still well below the OECD average at 79.5, or Finland at 80 and Sweden at 81.4 (OECD, 2011f). 
Figure 21. Health outcomes are weak

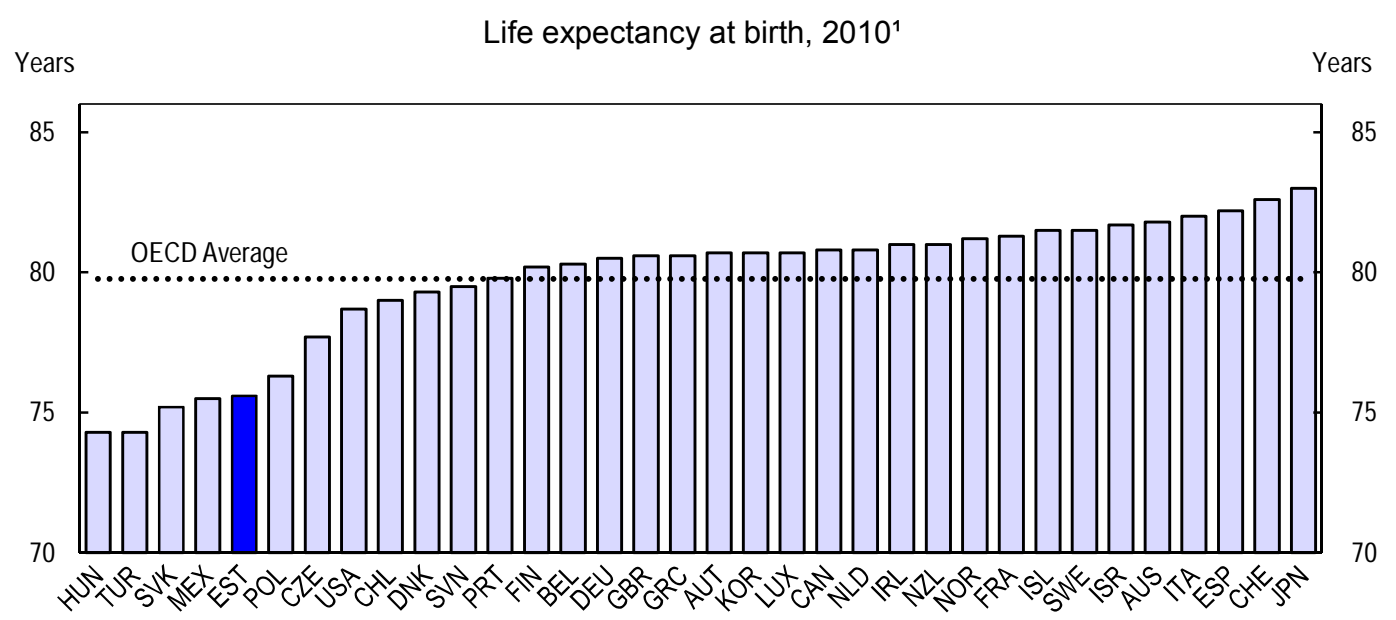

1. 2008 for Canada; 2009 for Italy.

Source: OECD Health database.

The gap in health status of those with less advantageous social backgrounds is also very large by international standards (Figure 22); in particular it is strongly differentiated by education, employment status and incomes (OECD, 2011a). Estonia has large income-related inequalities in health service use (Devaux and de Looper, 2012). This suggests that negative economic shocks can lead to health difficulties. A person at the top quintile is twice more likely to report good health than at the bottom quintile, while a person at the age of 30 with high education attainment has a life expectancy 17 years longer than one with low attainment. Estonia also has one of the highest premature mortality rates for males, double those of the country with the lowest rates, and as a consequence also the highest gap in life expectancy between men and women. While determinants of weak health outcomes and high health inequalities are complex and deeply rooted, improvement in access to public health services could make a positive difference (Figure 23, OECD, 2011f).

Figure 22. There is a large health gap due to income status

Adults reporting good or very good health by income quintile, 2009 or latest available year ${ }^{1}$

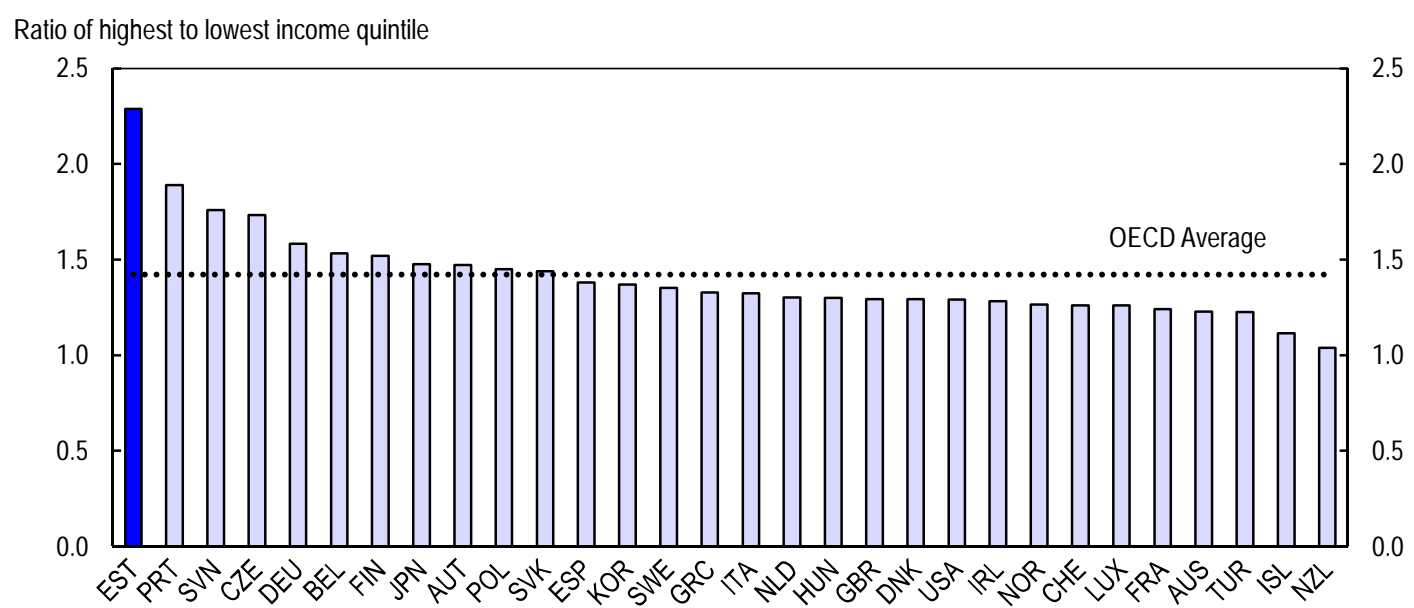

Note: Values refer to the ratio between the share of adults in the top income quintile reporting good or very good health to the corresponding share of adults in the bottom income quintile. Adults are generally defined as individual over 15 years old. 1. 2008 for Turkey; 2007 for Australia, Japan and New Zealand.

Source: OECD (2011), How's Life? Measuring well-being, Figure 5.8. 
Estonia's spending on healthcare, at $6.7 \%$ of GDP, was well below the OECD average of $9.6 \%$ in 2009. There is scope for a more efficient use of limited resources (Smidova, 2011). Expenditure was reduced in the crisis, and while the total number of cases was not reduced, waiting times doubled, co-payments were increased, dental care compensation was abolished and the quality of services has probably suffered. But while the fiscal space for expenditure increases remains limited, especially given strong spending pressures expected in the future due to ageing, there are significant opportunities for spending efficiency improvements. The priorities are to continue strengthening the primary care to eliminate avoidable hospitalization cases, combined with further rationalization of the hospital network and prudent financial management.

- While the number of practicing physicians is above the OECD average, the number of nurses is lower. This is linked to a traditionally doctor-centred health system that is currently changing. As a result of empowerment of family nurses in the primary health care team, the number of independent consultations of family nurses increased 15\%, while the number of preventive consultations of family doctors increased $2 \%$ and number of consultation because of health problems decreased by around $7 \%$. Positive changes also include a more effective quality performance pay system that is covering already $90 \%$ of family physicians. The gatekeeping function should be further enhanced to reduce the number of referrals (NAO, 2011). Shifting even more medical tasks to qualified nurses could make the provision of services more efficient while reducing waiting times, especially given the increasing lack of doctors in rural areas.

- The streamlining of the hospital network has been implemented since 2000, but while initial plans aimed at 19 hospitals with 2.2 beds per 1000 persons by 2015 , the changes stalled recently and there are still 3.6 beds per 1000 persons. The number of county hospitals remains high, considering the increased usage of regional and central hospitals by the rural population, and ensuring consistent resources and quality among local hospitals remains an important challenge. Converting some of the county hospitals into out-patient facilities therefore seems to be warranted (Smidova, 2011). EU structural funds in the new financial perspective 2014-20 could be used to support the reorganization process.

- Prudent financial management, including using the pricing power of national health insurance and fully implementing e-Health should continue to contribute to improving the efficiency of public health expenditures.

Figure 23. Access to adequate healthcare is an issue

Unmet need for medical examination for the bottom income quintile, 2009

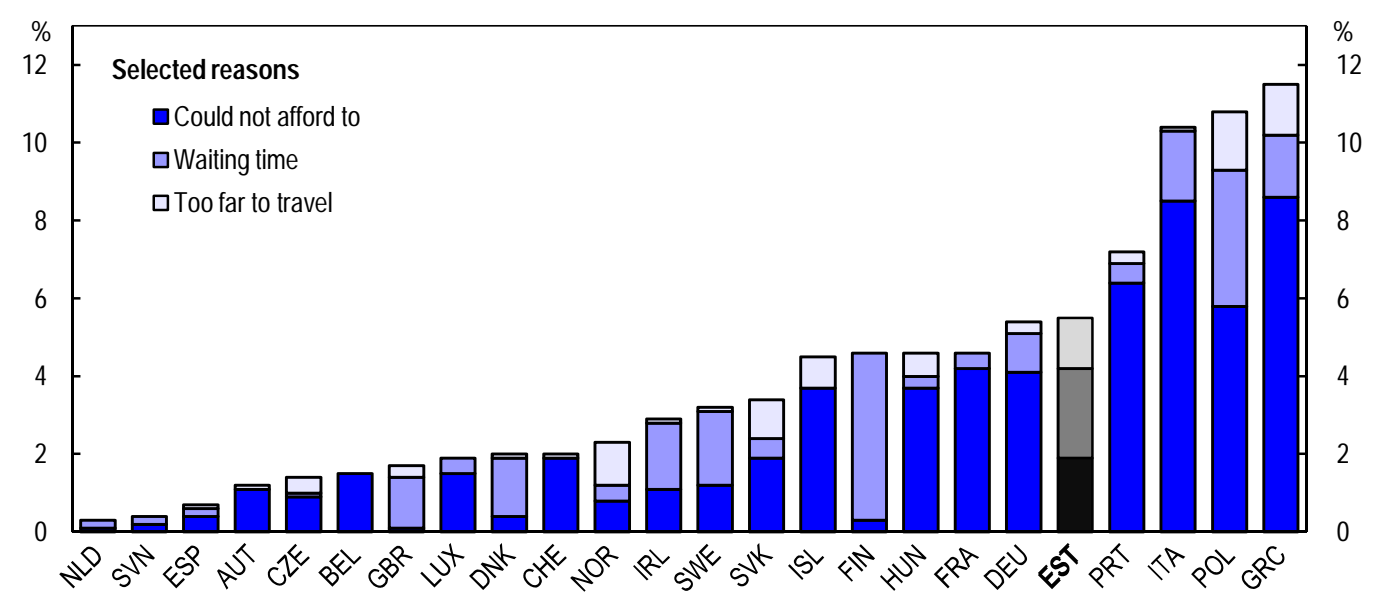

Source: OECD (2011), Health at a Glance, Figure 6.1.1. 
Low-income households face problems in accessing appropriate healthcare because of relatively high out-of-pocket payments (Smidova, 2011). While the share of such payments in total health spending is at the OECD average, the share of copayment for pharmaceuticals is particularly high, with households covering around $60 \%$ of costs compared with less than $20 \%$ in some countries (Figure 24). Introducing a means tested cap on out-of-pocket payments could therefore improve the access, as current caps are quite high and only pregnant women and children are exempted from copayments. Many municipalities choose to pay supplementary benefits to those who need them to buy medicinal products; however their financial capacities differ and lack of national guidelines might lead to unequal and insufficient access. The prescription and sales of generic drugs should be promoted more decisively to reduce the overall pharmaceutical bill. Access to dental care, which is not covered for adults, poses the most acute accessibility problem for those with limited means, so means-targeted financing could be considered.

Figure 24. High share of out-of-pockets spending on pharmaceuticals contributes to unequal access

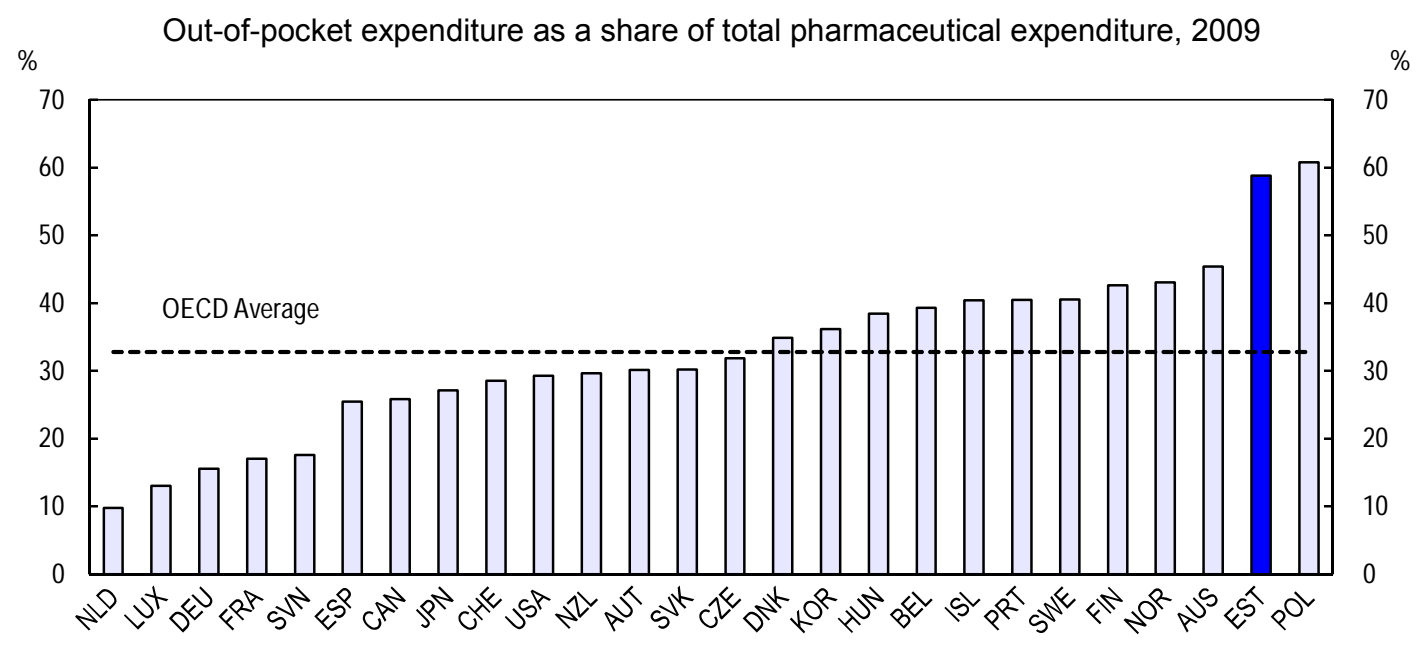

Source: OECD (2011), Health at a Glance, Figure 7.4.2.

Health care insurance requires contributions in the form of social tax, except for special groups - pensioners, pregnant women, persons below 19 years, students, and dependent spouses of insured persons. All registered unemployed are also automatically covered by health insurance. Health insurance therefore acts effectively as a compliance instrument for unemployment registration, and provides strong incentives for meeting associated requirements. It also mitigates the risk of free-riding on the public health system by those who work abroad and thus avoid paying taxes in Estonia. However, the current system also limits the access of some vulnerable groups. Municipalities are theoretically obliged to fund health care for the uninsured and in fact some health care costs are already being reimbursed to general physicians. However there are large regional differences in access, notably due to limited and regionally differentiated municipal resources. This policy might have negative medium-term consequences: lack of insurance might explain frequent use of state-funded emergency care in Estonia (NAO, 2011), accumulation of health problems and permanent deactivation, which can eventually lead to higher long-term costs. Extending coverage to the whole population should be therefore considered in line with a concept paper proposed by the Ministry of Social Affairs. Such a change could be accompanied by switching to tax based financing, with the potential benefit of reducing the labour tax wedge. 
Bad living habits contribute to poor health status, especially among males with lower social-economic background (OECD, 2011f). High rates of heart diseases and cancer are, in particular, linked to smoking, alcohol abuse, lack of physical activity and bad diet. Estonia is among countries with the highest consumption of alcohol, with 12.0 litres per adult per year in 2009 compared to 9.1 litres in the OECD on average. One in two men with only primary education smokes, while the share falls to one fifth for those with higher education. Comprehensive public health policies are therefore needed to reduce the health gap, starting from the programmes promoting healthy lifestyles at schools. Other types of socially harmful behaviour, such as drunk driving and speeding that contribute to high premature death rates, need also to be addressed more aggressively. Work-related accidents and diseases constitute an important health risk, particularly for those in low-skill occupations. Currently the system is based on the principle that the side proved guilty is paying, but this does not provide enough incentives for prevention as proving the responsibility is difficult (Praxis, 2011). This should be changed when a new insurance scheme is set up, so that the contribution is higher for employers and occupations with higher incidence rates.

\section{Reducing the labour tax wedge for the most vulnerable}

A high labour tax wedge is an important barrier for employment in Estonia, and reducing it especially for low-wage earners whose labour supply is usually more elastic, should be a policy priority. The average tax wedge is well above OECD norms (OECD, 2012b) due to high social security contributions and despite a relatively low level of personal income taxes. Reducing the tax wedge on labour would therefore facilitate the structural transformation and reduce the long-term unemployment rate (Brixiova and Egert, 2012). While the authorities consistently worked toward labour tax reduction in the boom period, the labour tax wedge was increased during the crisis, when the contribution rate to the Unemployment Insurance Fund was increased from 0.9 to $4.2 \%$ to provide funds for the increase in unemployment benefit spending and co-financing of active labour market policies. Beyond the reduction of the overall level of spending using existing but limited efficiency improvement opportunities, reducing relative taxation of low income earners and increasing the share of non-labour taxes should be pursued.

Authorities are currently planning a reduction of the unemployment contribution rate from $4.2 \%$ to $3 \%$ in 2012 and the personal income tax rate from 21 to $20 \%$ in 2015. Social insurance contributions will be capped at the level of three time the average wage, or EUR 4000 per month, in 2014. These are important steps confirming the commitment to lower the overall labour tax wedge. However, these changes do not do enough to address the most important challenge of average tax rates for low wage earners that are high in international comparison (Figure 25). The tax-benefit system also leads to an inactivity trap for persons with low earnings who could consider part-time work (Vork, 2009). In contrast, the marginal tax rate for high income individuals is below the OECD average. The greater labour market and social impact could be therefore achieved if the non-taxable tax allowance was increased instead of the reduction of the flat tax rate and social contribution capping. Such a reform would benefit disproportionally those at the bottom of the wage distribution. Similarly, partial subsidisation of social and unemployment insurance contributions for low earners could be effective in improving labour market outcomes, as evidenced by the generally successful programmes run in 2009-10. 
Figure 25. Low-earners face high labour tax wedge that discourages employment Average tax wedge on labour ${ }^{1}$ at $67 \%$ of average worker earnings, single person without children, $\%$ of compensation, 2010

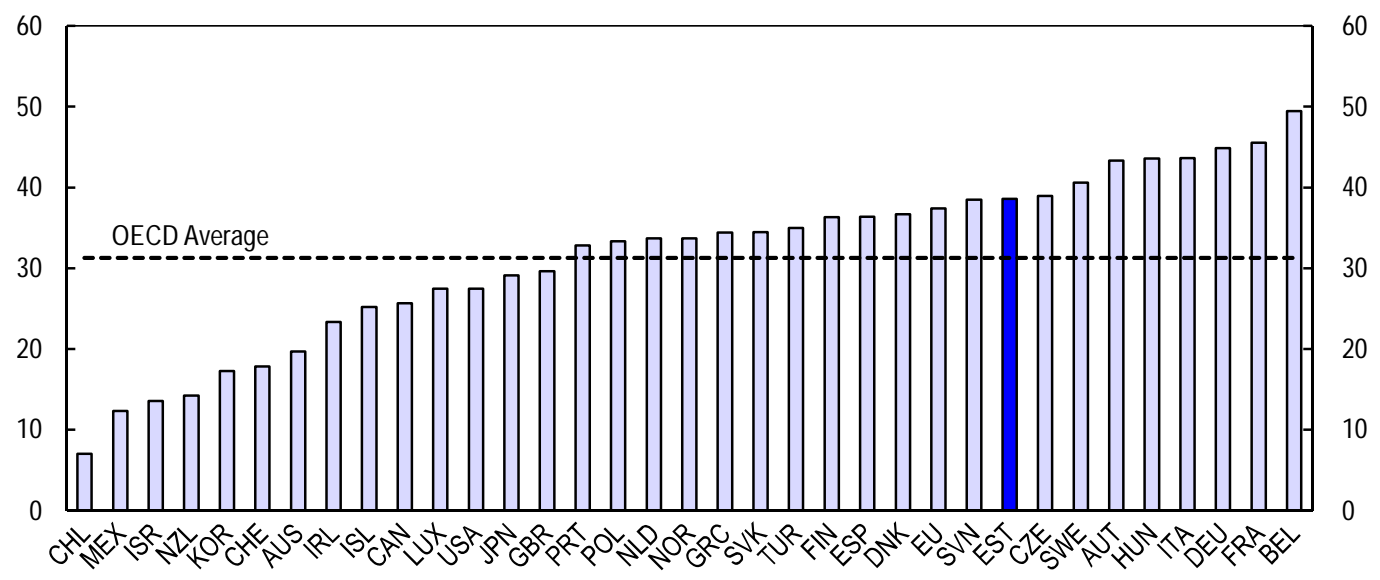

1. Measured as the difference between total labour compensation paid by the employer and the net take-home pay of employees, as a ratio of total labour compensation. It therefore includes both employer and employee social security contributions.

Source: OECD (2012), Going for Growth, Figure 3.3A.

Alternative sources for additional budgetary revenues exist and were discussed in previous Surveys (OECD, 2011d). They include property taxation, which is believed to be the least distortionary among all fiscal revenues (Johansson et al., 2008). In Estonia, the share of property taxation is currently the second lowest in the OECD (Figure 26), partly because only land is taxed and buildings are not. Increasing property taxes would not only bring additional non-distortive revenues, but it would also remove existing inefficiencies: under-taxation of property ownership is socially unfair, and it contributed to the previous housing boom (Brixiova et al., 2009).

Increasing land tax revenues would require aligning the property assessment more closely with the market value of land by more regular and market based updating assessments. Large scale revaluation, while not straightforward, is possible and it is for example being implemented in Portugal, where most of the housing stock is to be revalued by the end of 2012. In this respect, the decision to abolish taxation of land under individual houses in 2013 so as to reduce tax burden of homeowners seems counterproductive, limiting the efficiency of the tax system, and reducing the scope for the reduction of labour taxation.

Taxing buildings and apartments could also substantially expand the property tax base. Such change is, however, opposed partly because it would have a redistributive impact, in particular by taxing large number of beneficiaries of housing privatisation programme who sometimes do not have incomes corresponding to the market value of the acquired assets. However, such change could be implemented gradually, and the poorest could be initially protected. Such a change would have important positive side benefits: more efficient allocation of housing space, and reinvigorating the tenant market, which could also help to increase geographical mobility. Less favourable tax treatment of owner occupied housing could also reduce the risk of another housing price bubble (André, 2010). In this respect, limiting capital-gains-tax exemption to the sale of one permanent residence during a period of two years was a step in the right direction. The deductibility of mortgage interest payments should also be phased out (OECD, 2011d). This tax expenditure is equivalent to all spending on subsistence benefits. 
Figure 26. Property taxation is the source of potentially large non-distortionary revenues

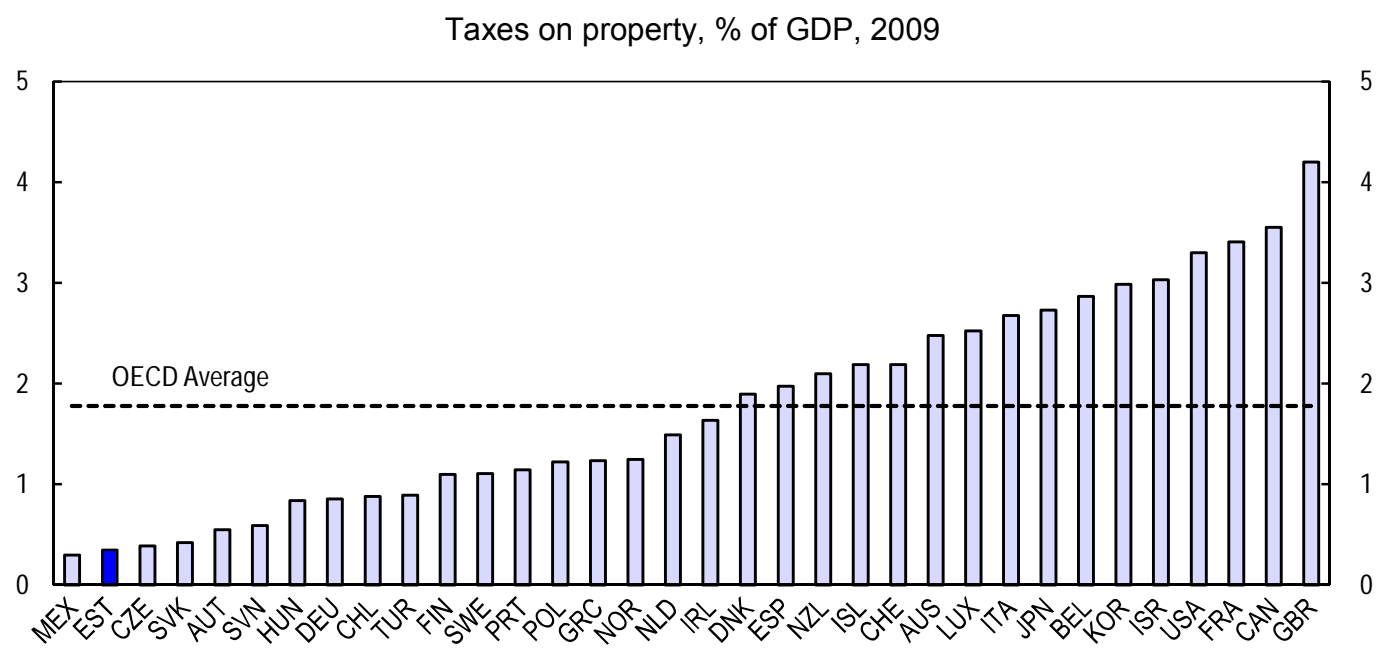

Source: OECD Revenue Statistics database.

Taxation of environmental externalities offers another opportunity for rebalancing the tax structure and addressing high emissions and low energy efficiency, important structural problems of the Estonian economy (government of Estonia, 2012). The share of environmental taxation continues to be below the EU average and ensuring that the costs of all negative global and local externalities are fully internalised by taxes will in itself increase the overall tax intake. In particular diesel seems to be under-taxed relative to petrol, when taking into account its environmental footprint. The existing lower excise duty rate on diesel fuel for specific purposes and on light heating oil should also be carefully reconsidered, its cost being close to $0.3 \%$ of GDP and being one of more important tax expenditures. The exemption in excise taxes for fuels used in the production of electricity is not appropriate, as it prevents a level playing field between small installations and large installations covered by the ETS. Exceptions for fuels for industrial, notably metallurgical and mineralogical processes should also be reviewed. Finally, the exemption for natural gas used for the purpose of operating the network might lead to an insufficient incentive for preventing network losses. In the longer term, designing appropriate road pricing could be considered to generate additional revenues, while being an effective tool in managing local externalities from transport, such as local pollution, congestion, noise and accidents (OECD, 2011d).

Although indirect taxation was increased as part of the fiscal consolidation in the crisis, and revenues are already at a relatively high level, there is still room to increase them. Further increases in excise taxes that are planned in 2012 and 2013 are welcome, both as important revenue sources as well as part of the struggle against health problems linked to alcohol and tobacco consumption. VAT administration could be further improved to reduce the gap between potential revenues and actual intake (ES, 2011). Phasing out remaining exemptions and reduced VAT tax rates could further increase the efficiency of the tax system, even if the list is relatively short compared to other EU member countries. The preferential $9 \%$ tax rate on accommodation services, periodical publications, books, and medicine and medical equipment should be abolished. The efficiency of such tax expenditures is low, as they are not targeted at those in greatest need, while their overall cost is twice as high as all targeted expenditure on unemployment assistance and subsistence benefits taken together. While increased in the crisis, standard VAT tax rates are still lower than in most OECD countries, and Nordic countries in particular, so there is scope for further increase. 


\section{Box 6. Recommendation on social protection}

\section{Activation}

- Refocus the social protection system on activation and return to work, underpinned with stronger inter-agency cooperation. Swiftly conclude analysis phase to prepare internet-based e-services. All working-age people with some capacity to work should become clients of local unemployment insurance fund offices and be encouraged to participate in job search and activation activities. In particular:

- Start preparing the reform of the disability pension system by opening activation measures to disability benefit recipients and strengthen the role of employers in prevention and rehabilitation measures.

- The role of subsistence benefits should be reduced and municipalities should focus on addressing other problems such as social exclusion, while unemployment assistance should become the main source of basic income support and be subject to tight job-search and training conditionality by unemployment insurance offices.

- Family support should be more oriented to better reconciling the obligations from parenthood and labour force participation, including through better provision of childcare services.

\section{Targeting}

- $\quad$ Benefits should be more targeted to help those in greatest need.

\section{Public services}

- Strengthening health spending efficiency, promoting healthy lifestyles and improving access for disadvantaged groups should be priorities to improve health outcomes and reduce health outcome gaps.

- $\quad$ Public sector delivery capacities of municipalities should be strengthened, including through incentives for service provision cooperation, including over a broad territorial area, and setting national service quality standards.

Tax incentives

- The high labour tax wedge should be reduced by increasing the share of less distortionary taxes, such as property and environmental taxes and excise duties and reducing tax expenditures, like preferential VAT rates. Reductions in direct taxes should be tilted towards low-earners.

\section{Bibliography}

d'Addio, A. and M. Mira d'Ercole (2005), “Trends and Determinants of Fertility Trends: The Role of Policies", Social, Employment and Migration Working Papers, No. 27, OECD Publishing.

Adsera, A. (2004), "Changing Fertility Rates in Developed Countries: The Impact of Labor Market Institutions", Journal of Population Economics, Vol. 17, pp. 17-43.

Ahrend, R., J. Arnold and C. Moeser (2011), "The Sharing of Macroeconomic Risk: Who Loses (and Gains) from Macroeconomic Shocks", Economics Department Working Papers, No. 877, OECD Publishing, http://dx.doi.org/10.1787/5kg8hw5467wd-en. 
André, C. (2010), “A Bird's Eye View of OECD Housing Markets”, Economics Department Working Papers, No. 746, OECD Publishing.

Atta-Darkua, V. and A. Barnard (2010), "Distributional effects of direct taxes and social transfers (cash benefits)", in Atkinson, A. and E. Marlier (ed.), Income and Living Conditions in Europe, Eurostat Statistical Books.

Brixiova, Z and Egert B. (2012), "Labour Market Reforms and Outcomes in Estonia," Comparative Economic Studies, Vol. 54(1).

Brixiova, Z., L. Vartia and A. Wörgötter (2009), "Capital Inflows, Household Debt and the Boom-bust Cycle in Estonia", OECD Economics Department Working Papers, No. 700, OECD Publishing, http://dx.doi.org/10.1787/224121736171.

Devaux, M. and M. de Looper (2012), "Income-Related Inequalities in Health Service Utilisation in 19 OECD Countries, 2008-2009”, Health Working Papers, No. 58, OECD Publishing.

EBRD (2011), Life in Transition. After the crisis, European Bank for Restructuring and Development, EBRD, London.

Flèche, S., C. Smith and P. Sorsa (2011), "Exploring Determinants of Subjective Wellbeing in OECD Countries: Evidence from the World Value Survey", Economics Department Working Papers, No. 921, OECD Publishing.

Fredriksson, P. and B. Holmlund (2006), "Improving Incentives in Unemployment Insurance: A Review of Recent Research", Journal of Economic Surveys, Vol. 20, No. 3.

Fusco, A., A. Guio and E. Marlier (2010), "Characterising the income poor and the materially deprived in European countries", in Atkinson, A. and E. Marlier (ed.), Income and Living Conditions in Europe, Eurostat Statistical Books.

Government of Estonia (2012), National Reform Programme “ESTONIA 2020”, government of Estonia, Tallinn.

Hilgeman, Ch. and C. Butts (2009), "Women's Employment and ertility: A Welfare Regime Paradox", Social Science Research, Vol. 38, pp. 103-117.

Hofmann, B. (2008), "Work Incentives? Ex-Post Effects of Unemployment Sanctions - Evidence from West Germany", IAB Discussion Papers, No. 43/2008, Institute for Employment Research, Nuremberg.

Kriisk, K. (2012). "Social benefits of Estonian local municipalities: local regulations and local budgets", Master thesis, Supervisor Prof. Lauri Leppik (PhD), Tallinn University Institute of Social Work, $160 \mathrm{pp}$.

Joumard, I., M. Pisu and D. Bloch (2012), "Less Income Inequality and More Growth - Are They Compatible?", Part 3: "Income Redistribution via Taxes and Transfers Across OECD Countries", Economics Department Working Papers, No. 926, OECD Publishing.

Lalive, R., J. Zweimuller and J. van Ours (2005), "The Effect of Benefit Sanctions on the Duration of Unemployment", Journal of the European Economic Association, Vol. 3, No. 6. 
Landais, C., P. Michaillat and E. Saez (2010), "Optimal Unemployment Insurance over the Business Cycle", NBER Working Papers 16526.

Lauringson, A. (2010), "Disincentive Effects of Unemployment Insurance Benefits: Maximum Benefit Duration Versus Benefit Level”, University of Tartu Working Papers.

Lauringson, A. (2011), "Unemployment benefits in the period of crisis: the effect on unemployment duration", University of Tartu Working Papers.

Lelkes, O. and E. Zólyomi (2008), "Poverty Across Europe: The Latest Evidence Using the EU-SILC Survey", European Centre Policy Brief, October.

NAO (2010a), Availability of state services in counties, Report of the National Audit Office to the Riigikogu, Tallinn.

NAO (2010b), The state's activities in supporting disabled people and persons receiving pension for incapacity for work. Does the support system meet its objectives?, Report of the National Audit Office to the Riigikogu, Tallinn.

NAO (2011), Overview of use and preservation of state assets in 2010. Auditor General's summary of observations made in the year, Report of National Audit Office for the Riigikou, Tallinn.

OECD (2006), "Boosting Jobs and Incomes: policy lessons from reassessing the OECD Jobs Strategy", free policy report, available at www.oecd.org/els/employmentoutlook/policylessons, OECD Publishing.

OECD (2009), OECD Economic Surveys: Estonia, OECD Publishing.

OECD (2010a), Sickness, Disability and Work: Breaking the Barriers. A Synthesis Finding, OECD Publishing.

OECD (2010b), OECD Reviews of Labour Market and Social Policies: Estonia, OECD Publishing.

OECD (2010c), OECD Economic Surveys: Germany, OECD Publishing.

OECD (2010d), OECD Economic Surveys: Australia, OECD Publishing.

OECD (2011a), How's Life?: Measuring well-being, OECD Publishing.

ECD (2011b), OECD Employment Outlook, OECD Publishing.

OECD (2011c), OECD Public Governance Reviews. Estonia. Towards a Single Government Approach, OECD Publishing.

OECD (2011d), OECD Economic Surveys: Estonia, OECD Publishing.

OECD (2011e), Doing Better for Families, OECD Publishing.

OECD (2011f), Health at a Glance. OECD Indicators, OECD Publishing.

OECD (2012a), OECD Employment Outlook, OECD Publishing. 
OECD (2012a), OECD Employment Outlook, OECD Publishing.

OECD (2012b), Going for Growth 2012, OECD Publishing.

Pisu, M. (2012), "Less Income Inequality and More Growth - Are they Compatible?", Part 5: "Poverty in OECD Countries", Economics Department Working Papers, No. 928, OECD Publishing, http://dx.doi.org/10.1787/5k9h28tlt0bs-en.

Praxis (2011), "Sustainable Financing Possibilities for the Estonian Social Security System”, Praxis, Tallinn, mimeo.

Price, R. and A. Wörgötter (2011), "Estonia: Making the Most of Globalisation", Economics Department Working Papers, No. 876, OECD Publishing, http://dx.doi.org/10.1787/5kg9pkmsmltc-en.

Rindfuss, R. et al. (2010), "Childcare Availability and Fertility", Population and Development Review, forthcoming.

Sjöberg, O. (2010), "Social Insurance as a Collective Resource: Unemployment Benefits, Job Insecurity and Subjective Well-being in a Comparative Perspective", Social Forces, Vol. 88, Issue 3.

Smidova, Z. (2011), "Public Sector Spending Efficiency in Estonia: Healthcare and Local Government", Economics Department Working Papers, No. 881, OECD Publishing, http://dx.doi.org/10.1787/5kg86qq1 k2vl-en.

Statistics Estonia (2010), Poverty in Estonia, Statistics Estonia, Tallinn.

Statistics Estonia (2011), Statics Yearbook of Estonia, Statistics Estonia,Tallinn.

Statistics Estonia (2012), Online statistical database, Statistics Estonia,Tallinn.

Thévenon, O. and A. Gauthier (2011), "Family Policies in Developed Countries: A 'Fertility-Booster' with Side-effects", Community, Work and Family, Vol. 14, No. 2, forthcoming.

Venn, D. (2012), "Eligibility Criteria for Unemployment Benefits: Quantitative Indicators for OECD and EU Countries", Social, Employment and Migration Working Papers, No. 131, OECD Publishing, http://dx.doi.org/10.1787/5k9h43kgkvr4-en.

Võrk, A. (2009), Labour Supply Incentives and Income Support Systems in Estonia, Institute for Labour Market Policy Evaluation Working Papers, 2009:31, IFAU, Tallinn.

Wolfers, J. (2003), "Is business cycle volatility costly? Evidence from surveys of subjective wellbeing", Research Paper Series, Stanford Graduate School of Business. 


\section{Annex 1.A1}

Risk-of-poverty rates by main categories

Table 1.A1.1. Risk-of-poverty rates by main population groups

\begin{tabular}{lrrrrrrrr}
\hline & 2003 & 2004 & 2005 & 2006 & 2007 & 2008 & 2009 & 2010 \\
\hline Estonia & 20.2 & 18.3 & 18.3 & 19.4 & 19.5 & 19.7 & 15.8 & 17.5 \\
By region & & & & & & & & \\
$\quad$ Northern Estonia & 12.5 & 10.9 & 11.9 & 11.1 & 11.1 & 11.3 & 10.1 & 10.4 \\
$\quad$ Central Estonia & 21.2 & 23.9 & 22.9 & 22.7 & 23 & 24.3 & 18.3 & 23.1 \\
$\quad$ Northeastern Estonia & 29.8 & 25.2 & 27.9 & 32.6 & 31.6 & 30.8 & 24.6 & 29.7 \\
$\quad$ Western Estonia & 21.8 & 20.1 & 19.6 & 21.6 & 23.8 & 24.1 & 19.2 & 15.9 \\
$\quad$ Southern Estonia & 25.8 & 23 & 20.8 & 23 & 22.8 & 23.2 & 17.7 & 20.8 \\
By education & & & & & & & & \\
$\quad$ Below upper secondary & & & & & & & & \\
$\quad$ education & 27.7 & 27 & 25.2 & 26.8 & 24.1 & 27.1 & 26.3 & 29.3 \\
Upper secondary education & 19.1 & 17.3 & 16.7 & 17.1 & 16.7 & 18.1 & 18.4 & 20.8 \\
$\quad$ Tertiary education & 11.5 & 9.4 & 8.8 & 7.5 & 6.1 & 5.3 & 6 & 7.9 \\
By age group & & & & & & & & \\
$\quad$ O-15 & 19.8 & 21.5 & 19.8 & 17.3 & 17.1 & 20.4 & 16.3 & 19.4 \\
$\quad \begin{array}{l}\text { 16-64 } \\
\text { 65 and older }\end{array}$ & 18.4 & 17.1 & 16.2 & 16.4 & 15.1 & 16 & 15.9 & 18.1 \\
By employment & 16.7 & 20.3 & 25.1 & 33.1 & 39 & 33.9 & 15.1 & 13.1 \\
$\quad$ Employed & & & & & & & & \\
$\quad$ wage employee & 9.6 & 7.5 & 7.5 & 7.7 & 7.3 & 8.1 & 6.4 & 7.9 \\
$\quad$ self-employed & 9.1 & 5.4 & 5.7 & 6.2 & 5.8 & 6.9 & 5.4 & 6.1 \\
$\quad$ Not at work &.. & 31.1 & 31.1 & 28.2 & 29.5 & 24.4 & 19.5 & 29.2 \\
$\quad$ unemployed & 27.1 & 29.7 & 31.6 & 35.9 & 38 & 35.4 & 25.9 & 26.8 \\
$\quad$ retired & 49 & 60 & 59.5 & 61.7 & 60.6 & 55.2 & 46.7 & 52.1 \\
$\quad$ other inactive & 19.4 & 22.8 & 28.7 & 36.9 & 43.3 & 37.9 & 17.9 & 14.9 \\
\hline
\end{tabular}

Note: The at-risk-of-poverty threshold is $60 \%$ of the median disposable income adjusted for household size.

Source: Statistics Estonia. 
ECO/WKP(2012)85

\section{Annex 2.A2 \\ Macroeconomic volatility and life satisfaction in Estonia: regression results}

According to the results of the surveys, the satisfaction with life as a whole and with the financial situation in Estonia was among the lowest across OECD countries, with the job satisfaction slightly below OECD average during the period 1996-2008 (OECD, 2011). In recent years, a large body of theoretical and empirical research has examined the determinants of household satisfaction (Flèche et al., 2011). According to some studies, economic insecurity and greater unemployment volatility significantly undermines perceived well-being (Wolfers, 2003; Sjöberg, 2010). This aversion to volatility can arise from several sources, although they are all based on convexity in individual preferences which induces an aversion to business cycle volatility.

To better understand what drives self reported satisfaction in Estonia, relative to other OECD European countries, and identify the impact of macroeconomic volatility on Estonia's well-being, additional empirical analysis was carried out. Research on determinants of well-being has been facilitated by the development of internationally comparable databases; the World Values Survey and the European Values Study provide answers to questions on life satisfaction in general, on satisfaction with financial situation, and on job satisfaction. For each question, the wording is roughly the same and its takes a format: "All things considered, how satisfied are you with your life as a whole these days?" The answer ranges from "dissatisfied" to "very satisfied" translated into 0-10 scale.

The effects of various explanatory variables on overall life satisfaction were estimated using macrodata and the data from the World Values Survey and the European Values Survey between 1996 and 2008. Unfortunately, more recent survey results, necessary to measure the impact of the economic crisis that started in 2008, are not available. Macroeconomic volatility is captured by standard deviations of real household disposable income and unemployment rates, computed for 5-year rolling periods between 1996 and 2008. Ordinary least squares were used for estimation, as the use of ordered probit makes little difference for life satisfaction data (Ferrer-i-Carbonnel and Frijters, 2004). The use of robust standard errors reduces heteroskedasticity problems, and inclusion of year fixed effects reduces the risk that macroeconomic shocks are also driving the correlations.

\section{Main results}

Table 1.A2.1 presents main results. The OECD cross-country panel macrodata regression (Column 1) confirms that income volatility is affecting negatively mean life satisfaction across OECD countries, on top of widely reported positive impact of average disposable income, and negative impact of aggregate unemployment rate. However, volatility in unemployment rate has insignificant impact on life satisfaction across the panel of countries. These patterns are confirmed by cross-country micropanel regressions that estimate determinant of life satisfaction at the level of individuals (Column 2), including all the most important individual characteristics (Flèche et al., 2011), and also for individual observations restricted only to Estonians (Column 3). In Estonia, however, the negative impact of unemployment volatility is significant at $10 \%$ significance level, unlike in the panel of OECD countries.

The two regressions based on microdata provide a source of further interesting observations, shedding light of specificities of life satisfaction determinant in Estonia that can be related to organization of social services in Estonia. Reported life satisfaction in Estonia seems to be more strongly correlated with individual level of income and employment status than in OECD on average. In particular, it is much more 
costly in terms of life satisfaction to be unemployed in Estonia than in other OECD countries. The negative impact of perceived inequality also seems higher than elsewhere. Being in good health is more important.

To sum up, macroeconomic fluctuations seem to entail consequences for the well-being of society, and the results suggest that, apart from increasing income and reducing unemployment rate, life satisfaction could be probably enhanced by smoothing business cycles, and strengthening social safety net to reduce fluctuations in household disposable incomes.

Table 1.A2.2. Detailed regression results: determinant of life satisfaction

\begin{tabular}{|c|c|c|c|}
\hline & $\begin{array}{c}\text { OECD countries } \\
1996-2008\end{array}$ & $\begin{array}{c}\text { OECD countries } \\
1996-2008\end{array}$ & $\begin{array}{c}\text { Estonia } \\
1996-1999-2008\end{array}$ \\
\hline & Macro data & \multicolumn{2}{|c|}{ Micro data } \\
\hline & Mean life satisfaction & \multicolumn{2}{|c|}{ Life satisfaction } \\
\hline \multicolumn{4}{|l|}{ Macroeconomic conditions } \\
\hline Household disposable income & $\begin{array}{l}0.116^{*} \\
(0.047)\end{array}$ & $\begin{array}{r}0.280^{*} \\
(0.014)\end{array}$ & $\begin{array}{r}0.538^{*} \\
(0.085)\end{array}$ \\
\hline $\begin{array}{l}\text { Household disposable income } \\
\text { standard deviation }\end{array}$ & $\begin{array}{l}-0.010^{*} \\
(0.003)\end{array}$ & $\begin{array}{l}-0.006^{*} \\
(0.000)\end{array}$ & $\begin{array}{l}-0.005^{*} \\
(0.000)\end{array}$ \\
\hline Unemployment rate & $\begin{array}{l}-0.119^{*} \\
(0.022)\end{array}$ & $\begin{array}{l}-0.043^{*} \\
(0.003)\end{array}$ & $\begin{array}{l}-0.065^{*} \\
(0.003)\end{array}$ \\
\hline $\begin{array}{l}\text { Unemployment rate } \\
\text { standard deviation }\end{array}$ & $\begin{array}{r}0.017 \\
(0.065)\end{array}$ & $\begin{array}{r}-0.003 \\
(0.009)\end{array}$ & $\begin{array}{r}-0.017 \\
(0.012)\end{array}$ \\
\hline Perceived income inequality & & $\begin{array}{l}-0.016^{*} \\
(0.003)\end{array}$ & $\begin{array}{l}-0.045^{*} \\
(0.013)\end{array}$ \\
\hline \multicolumn{4}{|l|}{ Labour force status } \\
\hline Being employed & & Omitted & Omitted \\
\hline Being unemployed & & $\begin{array}{l}-0.489^{*} \\
(0.038)\end{array}$ & $\begin{array}{l}-0.725^{*} \\
(0.150)\end{array}$ \\
\hline Being out of labour force & & $\begin{array}{r}0.090^{*} \\
(0.022)\end{array}$ & $\begin{array}{r}0.103 \\
(0.101)\end{array}$ \\
\hline Being student & & $\begin{array}{r}0.140^{*} \\
(0.036)\end{array}$ & $\begin{array}{r}0.291 \\
(0.163)\end{array}$ \\
\hline \multicolumn{4}{|l|}{$\begin{array}{l}\text { Demographic } \\
\text { characteristics }\end{array}$} \\
\hline Male & & Omitted & Omitted \\
\hline Women & & $\begin{array}{l}0.073^{*} \\
(0.015)\end{array}$ & $\begin{array}{l}0.221^{*} \\
(0.068)\end{array}$ \\
\hline Age & & $\begin{array}{l}-0.047^{*} \\
(0.003)\end{array}$ & $\begin{array}{l}-0.048^{*} \\
(0.013)\end{array}$ \\
\hline Age squared/1 000 & & $\begin{array}{r}0.520^{*} \\
(0.033)\end{array}$ & $\begin{array}{r}0.557^{*} \\
(0.140)\end{array}$ \\
\hline Single & & Omitted & Omitted \\
\hline Married & & $\begin{array}{r}0.397^{*} \\
(0.024)\end{array}$ & $\begin{array}{r}0.090 \\
(0.093)\end{array}$ \\
\hline Divorced & & $\begin{array}{l}-0.133^{*} \\
(0.039)\end{array}$ & $\begin{array}{l}-0.356^{*} \\
(0.129)\end{array}$ \\
\hline Separated & & $\begin{array}{l}-0.324^{*} \\
(0.058)\end{array}$ & $\begin{array}{r}-0.356 \\
(0.209)\end{array}$ \\
\hline Widowed & & $\begin{array}{l}-0.129^{*} \\
(0.043)\end{array}$ & $\begin{array}{l}-0.286^{*} \\
(0.149)\end{array}$ \\
\hline
\end{tabular}


Table 1.A2.1. Detailed regression results: determinant of life satisfaction (cont'd)

\begin{tabular}{|c|c|c|c|}
\hline & $\begin{array}{l}\text { OECD countries } \\
1996-2008\end{array}$ & $\begin{array}{l}\text { OECD countries } \\
1996-2008\end{array}$ & $\begin{array}{c}\text { Estonia } \\
1996-1999-2008\end{array}$ \\
\hline & Macro data & \multicolumn{2}{|c|}{ Micro data } \\
\hline & Mean life satisfaction & \multicolumn{2}{|c|}{ Life satisfaction } \\
\hline \multicolumn{4}{|l|}{ Education } \\
\hline Low education & & Omitted & Omitted \\
\hline Middle education & & $\begin{array}{l}-0.056^{*} \\
(0.021)\end{array}$ & $\begin{array}{r}0.076 \\
(0.124)\end{array}$ \\
\hline High education & & $\begin{array}{l}-0.069^{*} \\
(0.024)\end{array}$ & $\begin{array}{r}0.136 \\
(0.139) \\
\end{array}$ \\
\hline \multicolumn{4}{|l|}{ Health } \\
\hline Very good health & & $\begin{array}{r}0.816^{*} \\
(0.024)\end{array}$ & $\begin{array}{r}0.787^{*} \\
(0.137)\end{array}$ \\
\hline Good health & & $\begin{array}{r}0.355^{*} \\
(0.021)\end{array}$ & $\begin{array}{r}0.638^{*} \\
(0.086)\end{array}$ \\
\hline Satisfactory health & & Omitted & Omitted \\
\hline Bad health & & $\begin{array}{l}-0.856^{*} \\
(0.050)\end{array}$ & $\begin{array}{l}-0.936^{*} \\
(0.143)\end{array}$ \\
\hline Very bad health & & $\begin{array}{c}-1.435^{\star} \\
(0.184)\end{array}$ & $\begin{array}{c}-1.660 * \\
(0.405)\end{array}$ \\
\hline \multicolumn{4}{|l|}{ Community } \\
\hline Trust & & $\begin{array}{c}0.188^{*} \\
(0.016)\end{array}$ & $\begin{array}{c}0.338^{*} \\
(0.071)\end{array}$ \\
\hline Satisfaction with friends & & $\begin{array}{r}0.162^{*} \\
(0.012)\end{array}$ & $\begin{array}{r}0.024 \\
(0.052) \\
\end{array}$ \\
\hline \multicolumn{4}{|l|}{ Work-life Balance } \\
\hline Freedom of choice & & $\begin{array}{r}0.345^{*} \\
(0.004)\end{array}$ & $\begin{array}{r}0.382^{*} \\
(0.018)\end{array}$ \\
\hline Fixed effects & Yes & Yes & Yes \\
\hline Observations & 118 & 52692 & 3223 \\
\hline R-squared & 0.31 & 0.27 & 0.39 \\
\hline
\end{tabular}

Note: Robust standard errors in parentheses, ${ }^{*}$ denotes significantly different from zero at $5 \%$ level.

Source: World Values Survey and the European Values Study; OECD calculations.

\section{Bibliography}

Ferrer-i-Carbonnel and Frijters (2004), "How important is methodology for the estimates of the determinants of happiness?", Economic Journal, Vol. 117(497).

Flèche et al. (2011), "Exploring determinants of subjective wellbeing in OECD countries: evidence from the World Values Survey", Economics Department Working Papers, No. 921, OECD Publishing.

OECD (2011), How's Life? Measuring well-being, OECD Publishing.

Sjöberg, O. (2010), "Social Insurance as a Collective Resource: Unemployment Benefits, Job Insecurity and Subjective Well-being in a Comparative Perspective", Social Forces, Vol. 88, Issue 3. 
ECO/WKP(2012)85

\section{WORKING PAPERS}

The full series of Economics Department Working Papers can be consulted at www.oecd.org/eco/workingpapers/

1007. Matching skills and jobs in Estonia

(December 2012) by Lilas Demmou

1006. Debt and macroeconomic stability: An overview of the literature and some empirics

(December 2012) by Douglas Sutherland and Peter Hoeller

1005. Debt and macroeconomic stability: Debt and the business cycle

(December 2012) by Volker Ziemann

1004. Debt and macroeconomic stability: Case studies

(December 2012) by Rossana Merola

1003. Debt and macroeconomic stability

(December 2012) by Douglas Sutherland, Peter Hoeller, Rossana Merola and Volker Ziemann

1002. Reducing greenhouse gas emissions in a cost effective way in Switzerland.

(December 2012) by Anita Wölfl and Patrizio Sicari

1001. Strengthening innovation in the United States

(November 2012) by David Carey, Christopher Hill and Brian Kahin

1000. Long-term growth scenarios

(forthcoming) by Åsa Johansson, Yvan Guillemette, Fabrice Murtin, David Turner,

Giuseppe Nicoletti, Christine de la Maisonneuve, Philip Bagnoli, Guillaume Bousquet and

Francesca Spinelli

999. Selected aspects of household savings in Germany - evidence from micro-data

(November 2012) by Christina Kolerus, Isabell Koske and Felix Hüfner

998. Improving the tax system in Indonesia

(November 2012) by Jens Arnold

997. Unleashing business innovation in Canada

(November 2012) by Alexandra Bibbee

996. Public policy and resource allocation: evidence from firms in OECD countries

(October 2012) by Dan Andrews and Federico Cingano

995. Promoting SME development in Indonesia

(October 2012) by Annabelle Mourougane

994. Portugal: Rebalancing the economy and returning to growth through job creation and better capital allocation.

(October 2012) by Álvaro Pina and Ildeberta Abreu

993. Public debt, economic growth and nonlinear effects: Myth or reality?

(October 2012) by Balázs Égert 
992. Choosing the pace of fiscal consolidation

(September 2012) by Lukasz Rawdanowicz

991. Tertiary education developing skills for innovation and long-term growth in Canada (September 2012) by Calista Cheung, Yvan Guillemette and Shahrzad Mobasher-Fard

990. Trade and product market policies in upstream sectors and productivity in downstream sectors: firm-level evidence from China

(September 2012) by Maria Bas and Orsetta Causa

989. Intangible assets, resource allocation and growth: a framework for analysis

(September 2012) by Dan Andrews and Alain de Serres

988. Current account benchmarks for Turkey

(September 2012) by Oliver Röhn

987. Structural reforms to boost Turkey's long-term growth

(September 2012) by Rauf Gönenç, Oliver Röhn, Vincent Koen and Şeref Saygili

986. Tackling Turkey's external and domestic macroeconomic imbalances

(September 2012) by Oliver Röhn, Rauf Gönenç, Vincent Koen and Ramazan Karaşahin

985. Portugal: Solid foundations for a sustainable fiscal consolidation

(September 2012) by David Haugh and Stéphane Sorbe

984. Portugal: Assessing the risks around the speed of fiscal consolidation in an uncertain environment

(September 2012) by Stéphane Sorbe

983. The German labour market: preparing for the future

(September 2012) by Felix Hüfner and Caroline Klein

982. Climate change policies in Germany: make ambition pay

(September 2012) by Caroline Klein

981. Restarting the growth engine in Finland

(September 2012) by Henrik Braconier

980. Import Competition, Domestic Regulation and Firm-Level Productivity Growth in the OECD (September 2012) by Sarra Ben Yahmed and Sean Dougherty

979. Non-Parametric Stochastic Simulations to Investigate Uncertainty around the OECD Indicator Model Forecasts

(August 2012) by Elena Rusticelli

978. Measuring GDP Forecast Uncertainty using Quantile Regressions

(July 2012) by Thomas Laurent and Tomasz Kozluk

977. Implications of output gap uncertainty in times of crisis

(July 2012) by Romain Bouis, Boris Cournède and Ane Kathrine Christensen 